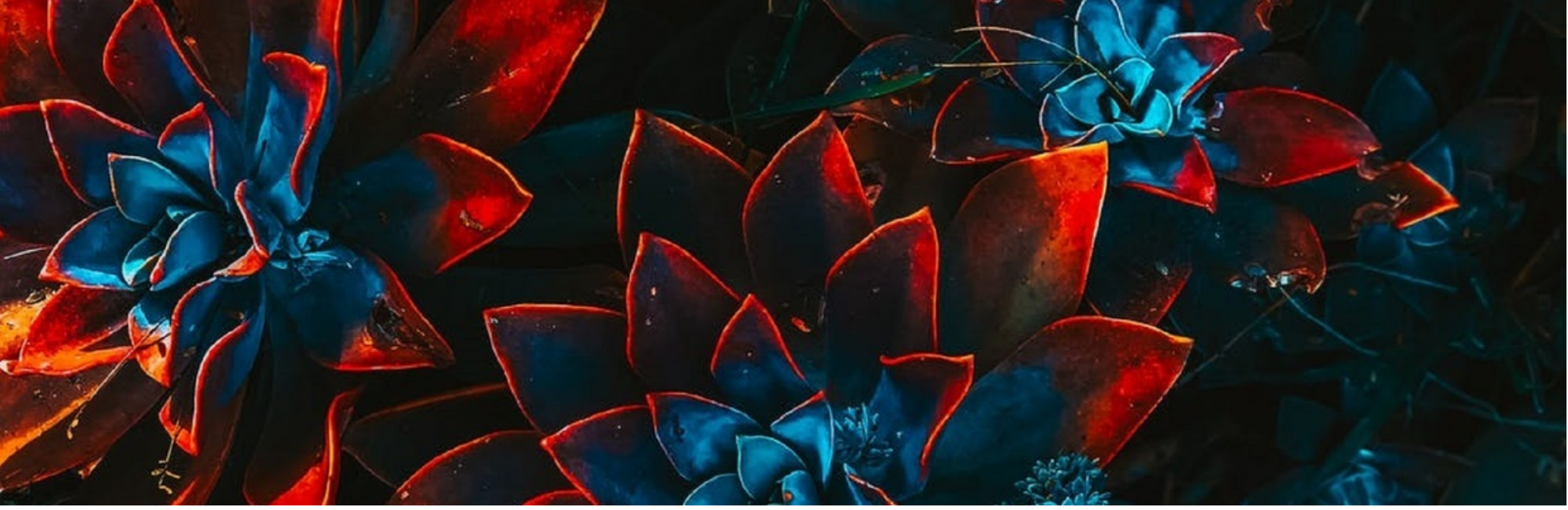

\title{
Mapmaking and Storytelling
}

$\begin{aligned} \text { Authors: } & \text { Chiara Giardi } \\ \text { Submitted: } & \text { 12. July } 2020 \\ \text { Published: } & \text { 13. July } 2020 \\ \text { Volume: } & 7 \\ \text { Issue: } & 4 \\ \text { Affiliation: } & \text { Albert-Ludwigs University of Freiburg } \\ \text { Languages: } & \text { English } \\ \text { Keywords: } & \text { Demetrios Project, Award 2020, competition, Humanities, Arts } \\ \text { Categories: } & \text { Demetrios Project, Humanities, Social Sciences and Law } \\ \text { DOl: } & \text { 10.17160/josha.7.4.698 }\end{aligned}$

Abstract:

In this thesis, I analyse artists' books and fanzines which were created for the exhibition 'Subjective Maps / Disappearances' in 2013 at the National Gallery of Iceland. The event was organized as part of the artistic research undertaken within Little Constellation, a contemporary art network with a focus on 17 geo-cultural micro-areas and small states of Europe such as San Marino, Iceland, Monaco, Gibraltar, and Cyprus. These areas and their communities are mostly understudied, systematically neglected in comparative analyses, and often only known through "uncertain" stereotypes such as tax havens, smugglers, or dutyfree shopping centers. For the exhibition, 37 artists born or based in these areas exhibited artists' books and fanzines that will become part of the permanent public collection of the San Marino National Gallery. A selection of the works was analyzed through a rhythmic analysis, taken from Henri Lefebvre, allowing the examination of time and space together. Due to their structure, artist's books are a particularly suitable genre to convey space-time narratives. The materiality and the intermediation experienced in their reading allow times and spaces to emerge in layers. In line with the whole Little Constellation project, the books could be considered 'research for art and design' on everyday practices in the small areas, where the thinking is embodied in the artifact. With this study, I contribute both to the discourse on how to analyse

\section{JOSHA Jumana ostamea Humanities and Arts}




\title{
MAPMAKING AND STORYTELLING:
}

\section{A GENRE-SPECIFIC RHYTHMANALYSIS OF ARTISTS' BOOKS FOR 'SUBJECTIVE MAPS / DISAPPEARANCES' \\ (NATIONAL GALLERY OF ICELAND, 2013)}

\author{
Bachelor thesis \\ submitted in partial fulfilment of the requirements \\ to obtain the academic degree of \\ Bachelor of Arts \\ in Liberal Arts and Sciences \\ at the University College Freiburg \\ of the Albert-Ludwigs-University Freiburg
}

submitted by

First and Last Name: Chiara Giardi

Matriculation Number: 4362090

Majoring in: Culture and History

First examiner (supervisor): Dr Ryan Plumley

Second examiner: Prof Dr Veronika Lipphardt

Date of submission: 30/05/2020 


\section{Abstract}

In this thesis, I analyse artists' books and fanzines which were created for the exhibition 'Subjective Maps / Disappearances' in 2013 at the National Gallery of Iceland. The event was organised as part of the artistic research undertaken within Little Constellation, a contemporary art network with a focus on 17 geo-cultural micro-areas and small states of Europe (e.g. San Marino, Iceland, Monaco, Gibraltar, Cyprus). These areas and their communities are mostly understudied, systematically left out in comparative analyses and often known only through "un-certain" stereotypes (e.g. tax heavens, smugglers, duty-free shopping malls). For the exhibition, 37 artists born or based in these areas exhibited artists' books and fanzines which are going to be part of the permanent public collection of the National Gallery San Marino. A selection of the works was analysed through rhythmanalysis, borrowed from Henri Lefebvre, allowing the examination of time and space together. Because of their structure, artists' books are a particularly well-suited genre to convey spatio-temporal narratives. The materiality and intermediality experienced in their reading allow layered times and spaces to emerge. Moreover, personal, situated narratives (i.e. exploring the social environment of the micro-area starting from myths, legends, beliefs or mental conditions) become a way to document and keep alive -through times and spaces of their own- what may disappear of the small territories of the network and individuals inhabiting them. In line with the whole Little Constellation project, the books could be considered 'research for art and design' on everyday practices in the small areas, where the thinking (with its spatiality and temporality) is embodied in the artifact. With this study, I contribute both to the discourse on how to analyse artists' books and fanzines (produced as artworks) and to the application of rhythmanalysis to the interpretation of contemporary art. 


\section{Table of Contents}

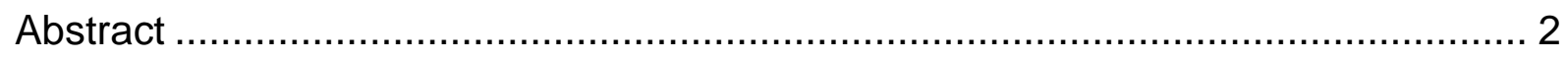

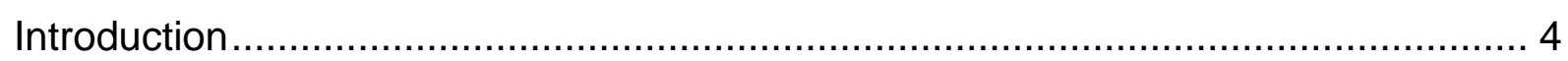

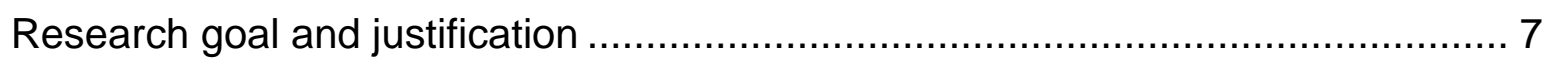

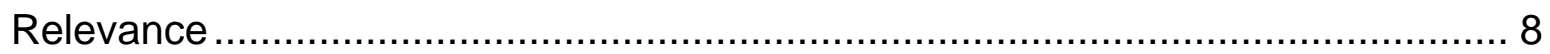

The exhibition: Subjective Maps and Disappearances ……................................ 11

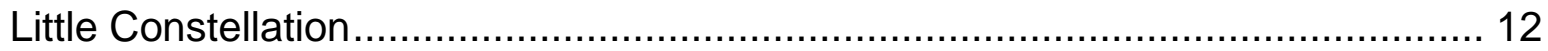

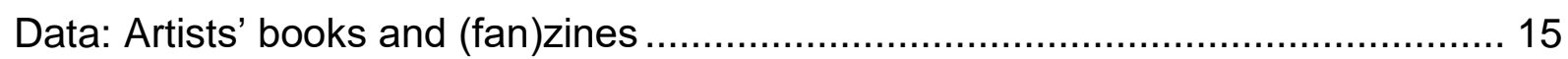

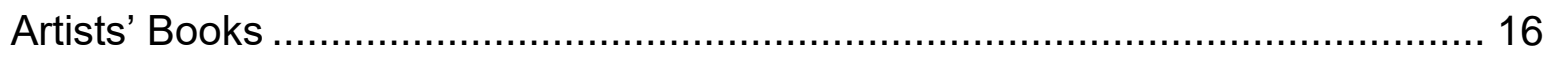

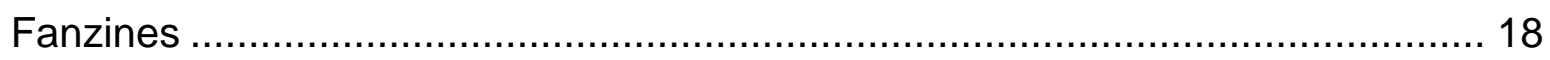

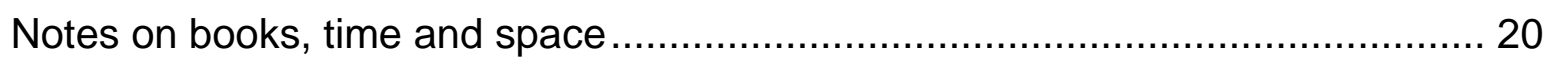

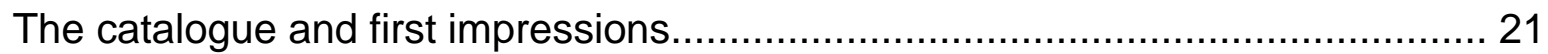

Method: Genre-specific rhythmanalysis .......................................................... 24

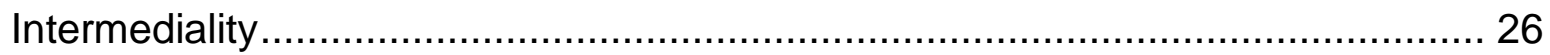

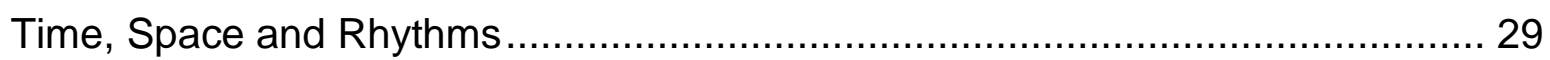

Analysis: Times, Spaces and Disappearances ................................................. 31

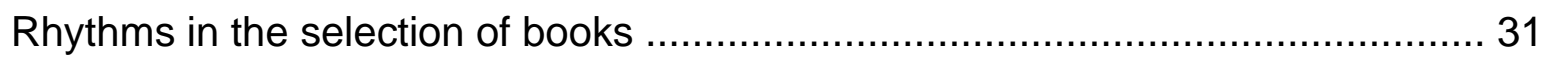

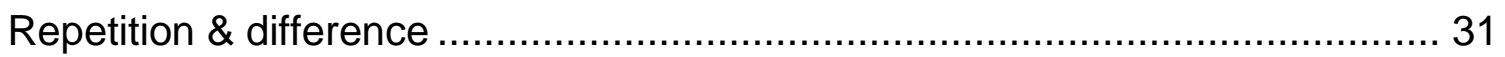

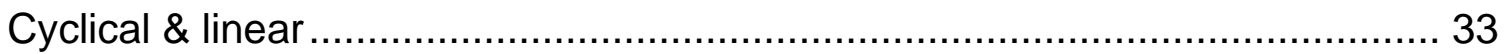

Symphonies in the books: eurhythmia, arrhythmia and polyrhythmia .................. 34

Polyrhythmia

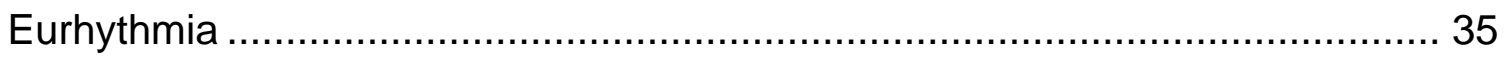

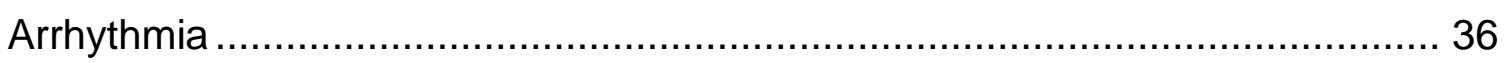

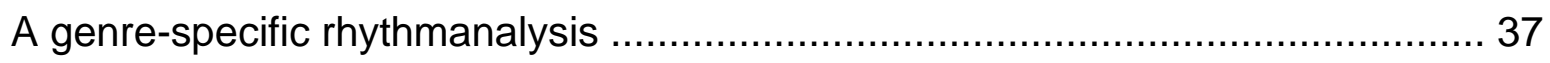

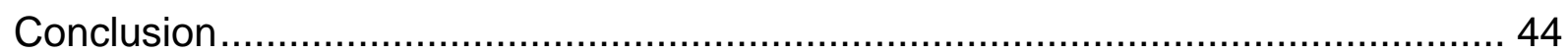

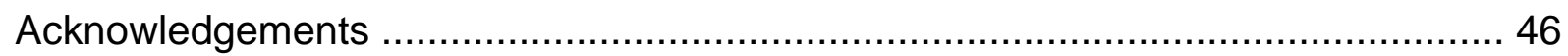

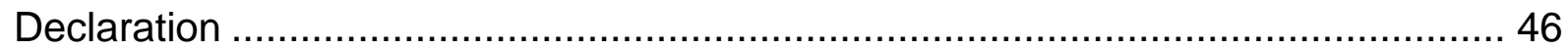

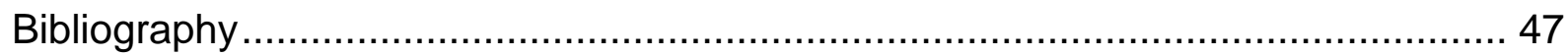

Annex A: List of Artists' Books and Fanzines ……........................................ 52 


\section{Introduction}

The exhibition 'Subjective Maps / Disappearances' was presented between the $17^{\text {th }}$ May and the $30^{\text {th }}$ June 2013 at the National Gallery of Iceland. It was the first event of the Reykjavik Arts Festival and it was curated by Halldór Björn Runólfsson (former director of the National Gallery of Iceland), Alessandro Castiglioni (Italian curator and art historian), Rita Canarezza and Pier Paolo Coro (Sammarinese artists and curators). 'Subjective Maps / Disappearances' was a project by Little Constellation, a network for contemporary art with a focus on geo-cultural micro-areas and small states of Europe (fig. 1). ${ }^{1}$ Members of the network included 17 small territories (below one million inhabitants) scattered around the -generally speaking- European continent: Andorra, Cyprus, Iceland, Liechtenstein, Luxembourg, Malta, Monaco, Montenegro, San Marino (the independent states) and Canton Ticino $(\mathrm{CH})$, Gibraltar (UK), Jersey and Guernsey (UK), Faroe Islands (DK), Åland Islands (FI), the more or less autonomous provinces and cities. Ceuta (ES) and Kaliningrad (RU), also part of the network, were not represented in this exhibition. ${ }^{2}$ These territories have nearly nothing in common except

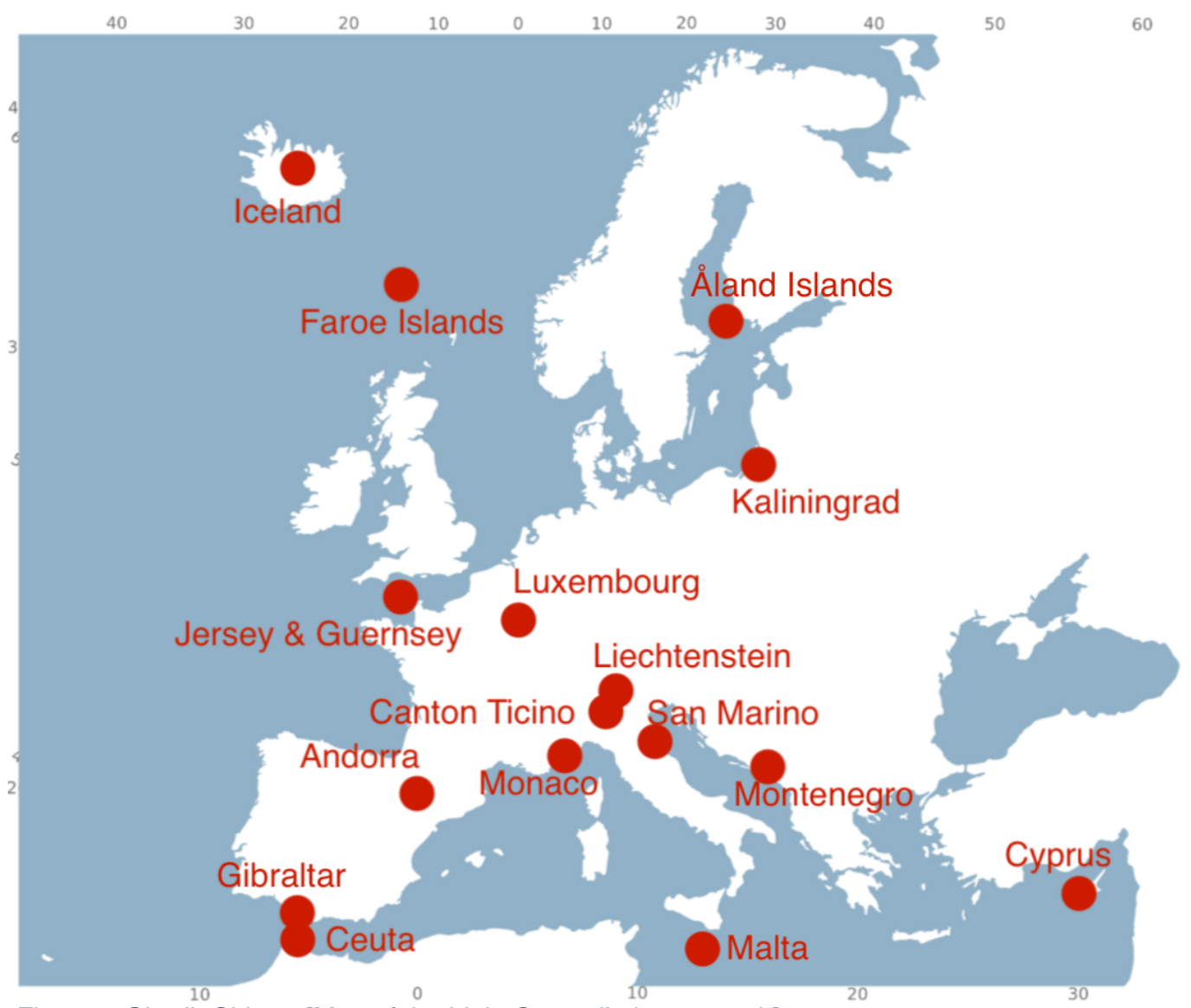

Figure 1 Giardi, Chiara, [Map of the Little Constellation network], 2020.

\footnotetext{
1 'Littleconstellation'.

${ }^{2}$ Giardi, Map of the Little Constellation Network.
} 
their -still different ways of- being 'small'. ${ }^{3}$ They have very different histories, geographies and political systems. However, they are all rather peripheral places regarding major European cultural hubs and they dispose of limited resources (money and workforce). To avoid confusion, and to follow Canarezza and Coro's will to go beyond the differences in diplomatic statuses, I will refer to all of them as 'small areas'.

For Subjective Maps / Disappearances, 34 unpublished artists' books and fanzines were created by artists who were born and/or based in these small areas (see Annex A for a list of the artworks). In the main hall of the National Gallery, the books were displayed on one big installation designed by Oppy de Bernardo 4 (Ticinese artist, also presenting a book). It was a 'constellation' of chunks of brown construction pipes which were anchored to the wall and on the ground to host the books (fig. 2). The hole was a metaphor for small areas: these places metaphorically escape the map: with maybe the exception of Iceland and Cyprus, they are so small that, on most geopolitical maps, they are signalled by empty circles. Moreover, construction pipes symbolised

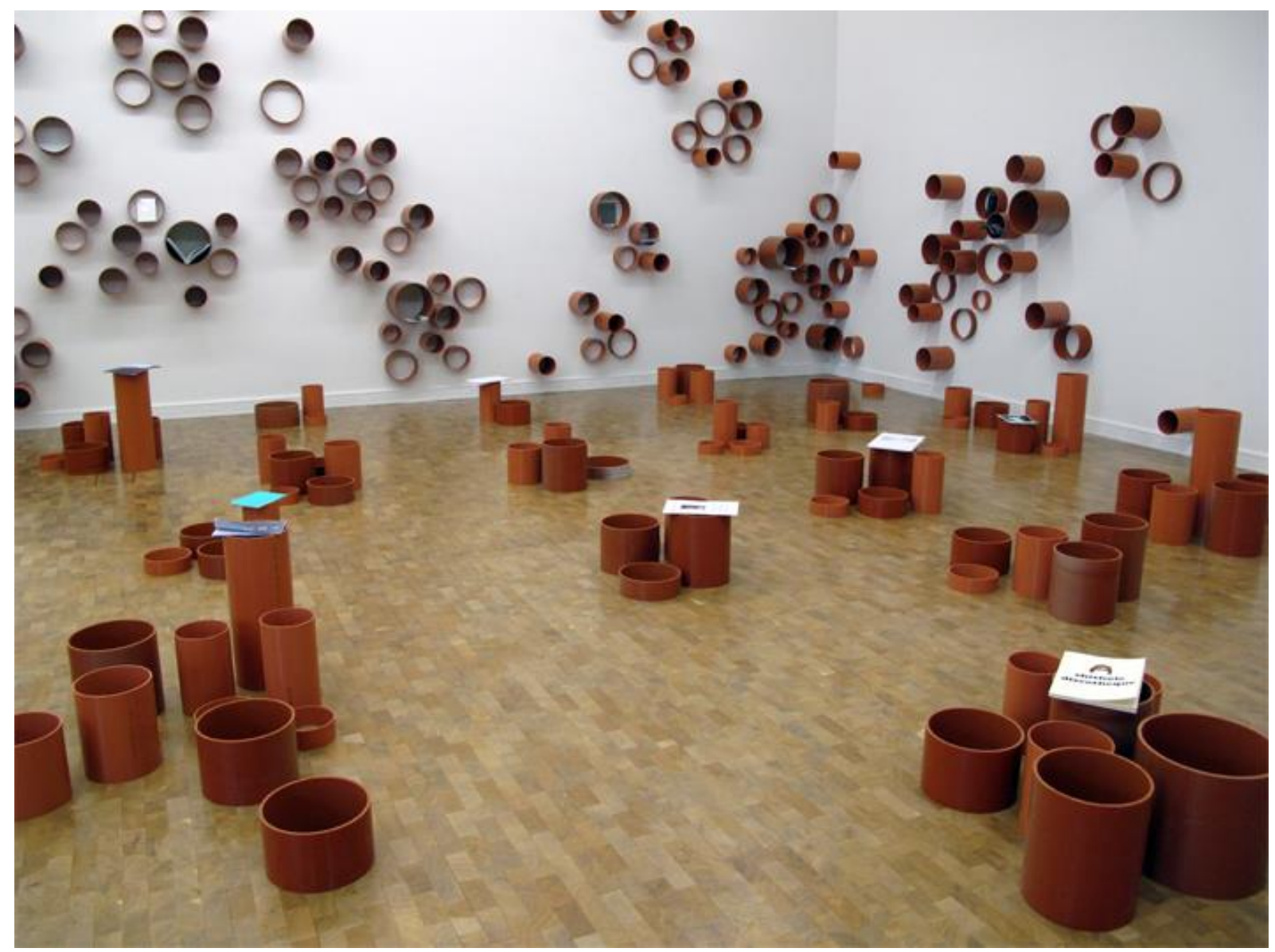

Figure 2 De Bernardo, Oppy, [Installation at the National Gallery of Iceland for Subjective Maps / Disappearances], 2013.

${ }^{3}$ Canarezza and Coro, On Little Constellation.

${ }^{4}$ De Bernardo, [Installation at the National Gallery of Iceland for Subjective Maps / Disappearances]. 
the connection and energy of the network. ${ }^{5}$ The public was allowed to walk around and carefully interact with the works in an environment which, according to Runólfsson, was somewhere between the Venice Biennale and the Frankfurt Book Fair: ${ }^{6}$ a simultaneous display of artworks and books.

After the exhibition, a copy of the artworks was archived by the National Gallery of Iceland and another was destined to the National Gallery San Marino, which finally opened in 2018. The artists' books and fanzines are now accessible in its Performative Archive (little dynamic library with room for research and education). Elena Rossi, who volunteered in 2019 at the National Gallery, undertook the art-historical analysis of three books. Prior to her work, no academic inquiry engaged with this material since 2013. This thesis expands on Rossi's work from a different and interdisciplinary perspective. I develop a genre-specific rhythmanalysis through which I look for time and space as emergent properties of the books. I complement this study with literature on the relevant subjects and an interview with the curators (Canarezza \& Coro, Castiglioni and Runólfsson).

In this thesis, I will argue that the materiality and intermediality of the books allow layered times and spaces to emerge through rhythms that narrate and/or counter various kinds of disappearances in specific geo-cultural contexts. In line with the whole Little Constellation project, the books could be considered 'research for art and design', where the thinking (with its spatiality and temporality) is "embodied in the artefact." I will first introduce the exhibition and its macro-theme 'Subjective Maps / Disappearances'. Second, I will give some background on my objects of inquiry (artists' books and fanzines) and my impressions reading/viewing ${ }^{8}$ them for the first time. Third, I will present my method (i.e. a genre-specific rhythmanalysis) exemplifying it on various artists' books. Finally, I present an analysis of Canarezza \& Coro's book.

\footnotetext{
${ }^{5}$ Canarezza and Coro, On Little Constellation.

${ }^{6}$ Runólfsson, On Subjective Maps / Disappearances.

${ }^{7}$ Frayling, 'Research in Art and Design': 5.

8 Tietz (2007) pointed out the difference between the act of reading and viewing artists' books, which underscores the dual nature of artists' books as literary and artistic/visual objects (see section on artists' books). Henceforth, my use of 'reader' (i.e. the person interacting with the object) and 'reading' (i.e. the interaction with the object to make meaning) entails both the action of reading texts and the one of viewing images.
} 


\section{Research goal and justification}

I defined my research goal starting from the concept of the exhibition. Reflecting on the statement that "mapmaking is a form of storytelling," I became interested in how an activity mostly focused on the documentation of spatial, synchronic relations (i.e. mapmaking) was merged with one centred in temporal ones, on the diachronic succession of events (i.e. storytelling). It soon became clear that time and space were not merely represented in the books. Their complexity, as simultaneously narrative objects and artworks, suggested that time and space were rather enacted through the works in the reading. Therefore, I drew on Katherine Hayles'10 reconceptualization of materiality, who defines it as a property which "emerges from the interplay between the text as a physical artifact, its conceptual content, and the interpretive activities of readers and writers." 11 In this way, materiality could not be understood as a pre-given characteristic, but rather as a relational, emerging one which needs interpretation and for that, the physical presence of a reader. Starting from Hayles' notion of materiality, I suggest that time and space emerge -together, in rhythms- in the relation between the reader and the artwork.

The problem of how to analyse the emerging times and spaces together brought me to the French philosopher Henri Lefebvre and his work on rhythmanalysis, ${ }^{12}$ which he intended as a new science, ${ }^{13}$ as a theory and a method. According to him, time and space are "distinguishable but not separable". ${ }^{14}$ Coming together in rhythms, they are not the arenas for something else to happen, they are (socially) produced in everyday practices. ${ }^{15}$ Rhythmanalysis also fitted the project because of the affinity between Henri Lefebvre's life-long work on the 'critique of everyday life' -of which rhythmanalysis is the last endeavour-and Little Constellation's research into everyday life through art practices in small geo-cultural areas. The similarity in research aims (i.e. the inquiry into everyday life in specific geo-cultural conditions) and the difference in means (i.e. an interdisciplinary re-working of Marxist philosophy and an artistic relational research, cross-bred with ethno-anthropological methods) makes, in my opinion, the dialogue between the two projects very fruitful.

\footnotetext{
${ }^{9}$ Canarezza et al., Subjective Maps: 6.

10 Hayles, 'Print Is Flat, Code Is Deep: The Importance of Media-Specific Analysis'.

11 Hayles: 72.

12 Lefebvre, Rhythmanalysis.

13 Lefebvre: 3.

14 Lefebvre, The Production of Space: 175.

15 Lefebvre: 26.
} 
Canarezza and Coro talk about their artistic work as research projects. ${ }^{16}$ Given the fact that within academia, especially in light of 'new' practice-based PhD programs, the meaning of research in the arts has been hotly debated, I would like to restate here its legitimacy. I consider the artists' books examined here the result of research projects, both because of the general modus operandi of Little Constellation and specifically of the exhibition prompt e.g. the presence of research questions, the communication of 'results' through publications and artworks, reference to previous work in the field (see following section). With extremely different methods, the artists inquired about and mapped, according to their individual points of view, the social, cultural, personal landscapes they experienced. Therefore, their methods should be set on a continuum with 'academic' practices like arts-based and creative methods ${ }^{17}$ and the overall endeavour could be termed 'research for art and design':

research where the end product is an artefact - where the thinking is, so to speak, embodied in the artefact, where the goal is not primarily communicable knowledge in the sense of verbal communication, but in the sense of visual or iconic or imagistic communication." ${ }^{18}$ (emphasis in original)

I see the mapping undertook for the artists' books as "a generous, open-ended, comparative and critical inquiry into the conditions and possibilities of human life in the one world we all inhabit", ${ }^{19}$ which, according to Tim Ingold, is the hallmark of anthropological art and research. Therefore, I suggest that the artists' books created for the exhibition embody an anthropological inquiry: a speculative (i.e. not meant to give a precise, nuanced -ethnographic- description $)^{20}$ research in everyday life which is shared by the Little Constellation project as a whole.

\section{Relevance}

The study of the artists' books and fanzines created for 'Subjective Maps / Disappearances' is relevant for various stakeholders. It is important for the National Gallery San Marino, as a museum and a public, national institution which is going to take care of these works. By acquiring these objects, the Gallery should not only make them accessible to the public but also guarantee for their conservation, carry out

\footnotetext{
${ }^{16}$ Canarezza and Coro, On Little Constellation.

17 Candlin, 'Practice-Based Doctorates and Questions of Academic Legitimacy': 4.

${ }^{18}$ Frayling, 'Research in Art and Design': 5.

${ }^{19}$ Research Centre Art \& Society, Keynote Speech Tim Ingold.

${ }^{20}$ Research Centre Art \& Society.
} 
research, communicate and publicise their contents. ${ }^{21}$ It is part of the mission of a national institution to collect and raise awareness on aspects of the (recent) history (of art) of the country: within Little Constellation, Sammarinese artists, public and private institutions were widely represented. Moreover, the whole project was deeply concerned with understanding the geo-cultural reality of the participant small areas, which makes the research highly relevant for all the respective populations. These territories "are often unique, unfamiliar to most people, not easily pigeonholed, and above all, have nothing in common with the stereotypical, reassuring visions of happiness that tourist catalogues proffer to us from every corner of the globe". ${ }^{22}$ If known at all, the European small areas are often stereotyped (e.g. anachronistic fake medieval fortresses, tax heavens, weapon traders, smugglers and duty-free shopping centres). However veritable to some extent, these façades hide deeper complexities and contradictions. Pier Paolo Coro called these small areas Territori ad Alta Definizione Simbolica (Territories of High Symbolic Definition) ${ }^{23}$ because they look as if under a spotlight or magnifying lens. There, not only news and rumours circulate fast, like in villages, but also everything becomes of 'national' relevance. In these little communities one could notice distortions of aspects of bigger nations ${ }^{24}$ (e.g. I think about personalistic politics ${ }^{25}$ and nepotism). The micro/local and the macro/global dimension of the state and the institutions coincide in smallness: ${ }^{26}$ according to Lluís Mallard i Casamajor and Jordi Domingo i Coll in these areas one notices a "close coexistence $\ldots$ between antithetical situations and antinomic concepts -local and international, interior and exterior, tradition and modernity, large and small, entering and exiting, border and transborder". ${ }^{27}$ The overlap of these opposites fosters dynamics that are rarely seriously studied and thus poorly understood. ${ }^{28}$ Microstates are "persistently excluded from comparative political research," 29 and very few researchers have ventured beyond the mere examination of quantitative data. ${ }^{30}$ For example, it is well known that microstates have (or had) some of the highest income

\footnotetext{
21 'ICOM Statutes'.

${ }^{22}$ Castiglioni, Canarezza, and Coro, The Land Seen from the Sea: 8.

${ }^{23}$ Canarezza and Coro, Little Constellation: Small States on Un-Certain Stereotypes.

${ }^{24}$ Canarezza and Coro, On Little Constellation.

25 Veenendaal, 'Size and Personalistic Politics'.

${ }^{26}$ Canarezza and Coro, On Little Constellation.

${ }_{27}$ Mallard i Casamajor and Domingo i Coll, 'Small communities with big complexities in the sphere of interaction': 51.

${ }^{28}$ Klieger, Microstates of Europe: (Kindle book without page).

${ }^{29}$ Veenendaal, 'Size and Personalistic Politics': 245.

30 Veenendaal: 245.
} 
per capita and life expectancies, but how this came about and with what impact on the community remains mostly a matter of speculation (with very few interesting exceptions). ${ }^{31}$ The research carried out by ad hoc research centres and projects (e.g. the Centre for Small States Studies at the University of Iceland) remains a niche literature. It is hard to find and rarely translated, whether into English to be internationally available, or into the local languages for the population to access it. Given this state of affairs, this study builds on the breadth and depth of the projects undertaken within Little Constellation by analysing some of its output. With the first comprehensive academic study of the material produced for 'Subjective Maps / Disappearance', this thesis potentially paves the way to events and publications to raise awareness about that research and its relevance for the population in San Marino and the other small areas.

Moreover, I aim at expanding the discourse on artists' books and fanzines as objects of inquiry, especially on questions of time and space through materiality ${ }^{32}$ and intermediality. ${ }^{33}$ The "physicality of sound," 34 and "rhythms" 35 come often up in the analysis of artists' books. However, to the best of my knowledge, rhythms were never applied as a central analytical category. Specifically, rhythmanalysis was mostly employed to study everyday rhythms from a human geography perspective. Rhythmanalytical studies may include concepts of performance and practice, use photography ${ }^{36}$ and drawing as data, walking as method ${ }^{37}$ and other aspects which border research in contemporary arts. However, these projects kept the disciplinary perspective of (human/cultural) geography e.g. they examined street performance to understand practices in public spaces, not as forms of art. An exception to this could be the use of rhythmanalysis to study specific media, such as TV ${ }^{38}$ or literature. ${ }^{39}$ Therefore, this study not only draws on art history, literary and media studies, which were especially helpful in tracing genealogies, challenges and developing sensibilities, but it also bridges to the spatial humanities, human/cultural geography and especially Lefebvre's legacy in these fields.

\footnotetext{
31 Veenendaal, 'The Economic Crisis and the Republic of San Marino: A Comparative Case Study'.

32 Hayles, 'Print Is Flat, Code Is Deep'.

33 Rajewsky, 'Intermediality, Intertextuality, and Remediation'.

34 Bury, Artists' Books: 7.

35 Tietz, 'Artists' Books: Between Viewing and Reading': 20.

36 Simpson, 'Apprehending Everyday Rhythms'.

${ }^{37}$ Chen, "Walking With"'.

38 Obert, 'Sound and Sentiment'.

${ }^{39}$ Morton, 'The Warp of the World'.
} 


\section{The exhibition: Subjective Maps and Disappearances}

'Subjective maps' and 'Disappearances' were the keywords of the exhibition. The interest in disappearances started during a Little Constellation workshop in Reykjavik in November 2011.40 On that occasion, Runólfsson introduced the participants to the prominence of disappearance as a theme in Icelandic folktale tradition. These tales often feature people who never came back, sea monsters and calamities. ${ }^{41}$ According to one story, the 'hidden people' (Huldufólk) roam the island because Eve, upon God's unexpected visit, presented only the children she had washed. ${ }^{42}$ Disappearances still mark Icelandic recent history, where unexplainable facts and religious beliefs mingle with crime. ${ }^{43}$

Jorge Luis Borges often visited Iceland and got inspired by Icelandic tales (see 'The book of imaginary beings'44) In turn, his famous piece "On Exactitude in Science"45 connects the theme of mapping. ${ }^{46}$ In the short story, the cartographers of the empire became so precise at drawing maps that they created one which was as big as the empire itself. The useless and pitiful map was then consigned to the elements by the following generation. The short story suggested the recollection of stories of disappearance as a way to subjectively map one's environment. Subjective mapping was understood as a way to counter and to narrate disappearance, to document -in a deliberately personal way- through stories, fictions, folktales, legends and myths what might get lost.

Two research questions were developed: "Nowadays, must a small community, embedded in a context of international institutions, fear erasure? For an individual who is part of a social system, what it mean [sic] to disappear?"47 Canarezza and Coro explain that "anything could happen" 48 in small areas. Notwithstanding the widely celebrated "importance of being unimportant - the power of being powerless," 49 they are rather vulnerable places, mostly de-militarized, dependent on the "benign

\footnotetext{
${ }^{40}$ Canarezza et al., Subjective Maps: 6.

${ }^{41}$ Canarezza et al: 8.

42 Canarezza et al: 9.

${ }^{43}$ Runólfsson, On Subjective Maps / Disappearances.

${ }^{44}$ Borges, Guerrero, and Di Giovanni, The Book of Imaginary Beings; Canarezza et al., Subjective Maps: 6.

45 Borges, 'On Exactitude in Science'.

${ }^{46}$ Castiglioni et al., The Land Seen from the Sea: 22.

47 Canarezza et al., Subjective Maps: 6-7.

48 Canarezza and Coro, On Little Constellation.

${ }^{49}$ Baldacchino, 'Bursting the Bubble': 38.
} 
protection" 50 of the neighbours and/or the central states. From a political-scientific point of view, microstates seem rather odd cases of unlikely survivors "given the widely held sentiment that globalism will ultimately triumph." ${ }^{51}$ This sentiment may not be scientifically founded, but it would still justify some kind of 'existential angst' in small and explicitly non-self-sufficient areas.

However, the artists interpreted the meaning of both subjective maps and disappearances in completely different and creative ways. For example, some artists worked on the symbolic meaning of specific areas (e.g. the scratchings on the walls of the merchant's street in Malta); some others explored places according to mental conditions (e.g. Monaco harbour through the syndrome of a princess who lost her crown) and some re-worked local folktales (e.g. 'the people of the night' set in contemporary Liechtenstein). The meaning often depended on the geo-cultural history of the country of origin. In Iceland, the points of reference could be the recurrent disappearance of people in a big wild country, the presence of supernatural populations and the imaginary maps of the interior of the island (mostly uninhabited) being a paradise hidden in the valleys populated by outlaws. ${ }^{52}$ In San Marino, it could be the relationship with 'the big neighbour' what connoted 'disappearance' and suggested the times and places to map. Canarezza \& Coro devoted to the trade-offs in the San Marino-Italy relations parts of their work called 'short stories of nonindependence'. For example, during the fascist period, the licence for an independent radio was renounced in exchange for an electric railway between Rimini -the nearest 'big' Italian city- and San Marino. This and many more stories, partially presented in the analysis, become the symbolic base onto which a possible disappearance is grounded.

As the last point in this first section, I would like to introduce Little Constellation to give more background on the bigger research project the Icelandic exhibition was part of.

\section{Little Constellation}

Little Constellation "is an international network on contemporary art aiming to organize and promote projects with a specific focus on the current research activity in

\footnotetext{
50 Dumienski, 'Microstates as Modern Protected States: Towards a New Definition of MicroStatehood': 4.

${ }^{51}$ Klieger, Microstates of Europe.

${ }^{52}$ Runólfsson, On Subjective Maps / Disappearances.
} 
the small states of Europe ... and in a few European micro-areas. ${ }^{53}$ Little Constellation started as a research project in 2004 by the Sammarinese artist duo Rita Canarezza and Pier Paolo Coro with the question: "how is the practice of making art experienced today in certain geocultural micro-areas and small states of Europe?"54 This artistic ethno-anthropological research project (the artists reference Bronisław Malinowski's ${ }^{55}$ method) ${ }^{56}$ grew in different phases to include 17 small areas. It was documented through diaries, photo and video material. It included highlights of the long journeys by car and by ferry to physically connect the various places, meetings with major local artists, interviews with museums/galleries representatives and local/governmental institutions. These offices typically overlapped e.g. major artists were also working in the institutions, as in Canarezza's case.

The chosen symbology for the network, a little constellation, embodied the spirit of the inquiry. The artists aimed at building long terms relationships between very different and autonomous entities which "sparked of their own light". ${ }^{57}$ These 'faraway' places had the sci-fi aura of mysterious worlds inhabited by different populations. However, the constellation also symbolised a kind of dispersion within the various entities, so small and apparently compact and yet internally so fragmented into various institutions (fig. 3). ${ }^{58}$ Art publications documented and concretized important steps of this big dematerialized relational ${ }^{59}$ artwork. The legacy of the book as an object to archive knowledge can be seen in the choice of artists' books for the Icelandic exhibition. Every publication included a visualization of the network as a "little (big) constellation"60 with special logos designed by the publisher for each micro-area (fig. 3). ${ }^{61}$

Different projects took shape within the network, such as workshops in the major institutions (e.g. MUDAM in Luxembourg, 2011), exhibitions in Bologna (Galleria Neon Campobase, 2009), Milan (La Fabbrica del Vapore, 2010), Genoa (Museo Villa Croce, 2012), Reykjavik (National Gallery of Iceland, 2013) and the foundation of a contemporary art centre in Gibraltar (Listen to the sirens, 2014). Each project revolved around life and art practice within and/or from the perspective of European micro geo-

\footnotetext{
53 Little constellation: contemporary art in geo-cultural micro-areas and small States of Europe: 146.

54 Little constellation: 33.

${ }_{55}$ Malinowski, Argonauts of the Western Pacific.

56 Little constellation.

57 Canarezza and Coro, On Little Constellation.

58 Canarezza and Coro.

59 Bourriaud, Relational Aesthetics.

60 Daolio, 'Little (Big) Constellation': 42.

61 '[Map of Little Constellation for Subjective Maps / Disappearances]'.
} 


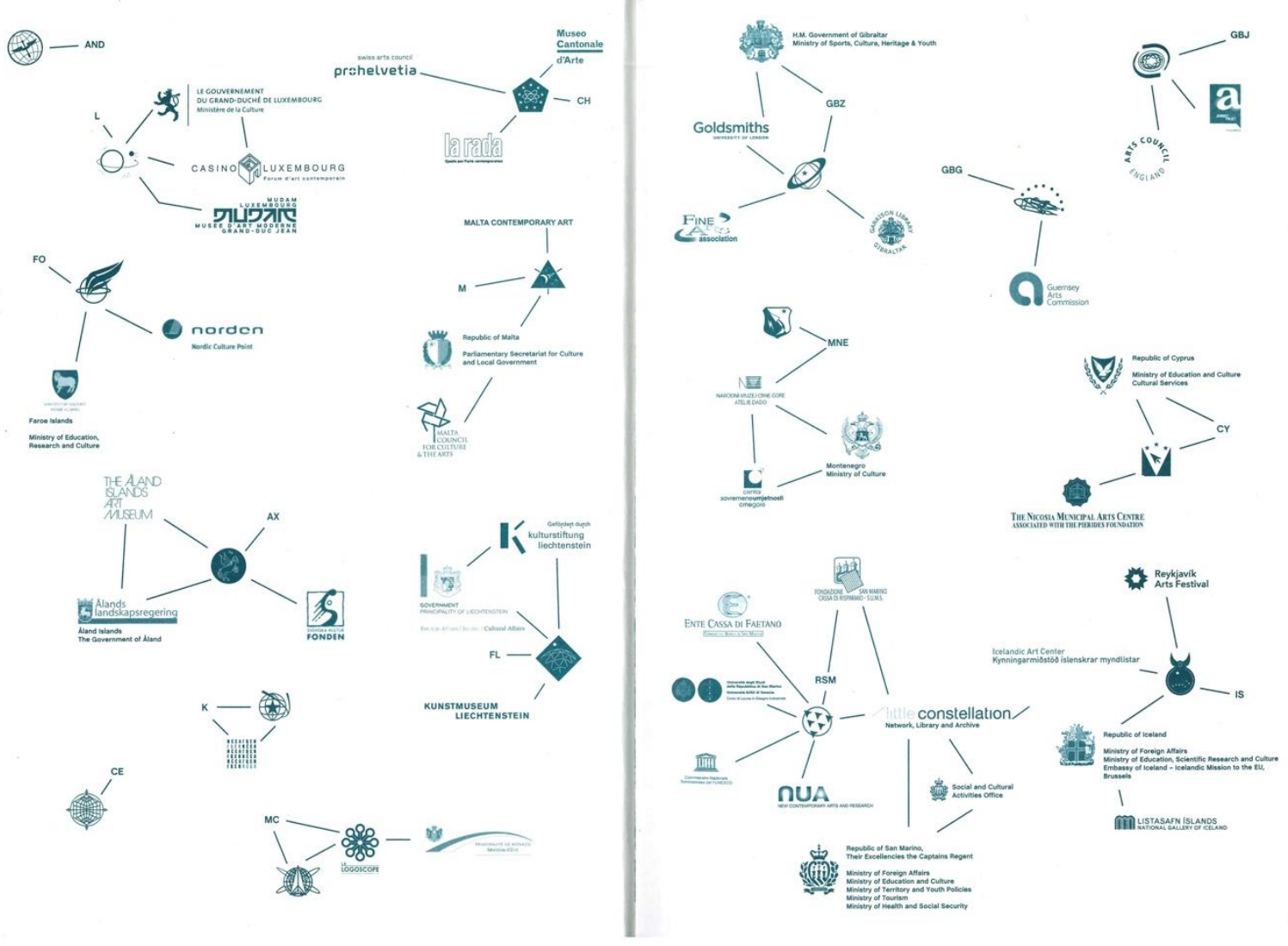

Figure 3 [Map of Little Constellation for Subjective Maps / Disappearances], 2013.

cultural areas. For example, 'The Land Seen from the Sea', had the "goal of developing a perspective on the state of art, the practice of travel and the perception of distance, in specific geographic areas." 62 Indeed, far from being a self-contained project, the Icelandic exhibition was another, very important step in a broader exploration of the multifaceted experience of life and art practice in particular contexts, where the 'geographic' and the 'cultural' cannot be easily taken apart:

Unless it develops a culture, a community cannot differentiate itself in time and space. It can only be recognized and associated with a given landscape. If culture fades, there will be no landscape. And without a landscape, there is no geography, or community"63

In this first section, I gave some background on the research project that led to the exhibition and that profoundly shaped its focus on 'subjective maps' and 'disappearances'. In the next ones, I delve deeper into my data and methodology, explaining what exactly I analysed and how.

\footnotetext{
62 Castiglioni et al., The Land Seen from the Sea: 7.

${ }^{63}$ Mallard i Casamajor and Domingo i Coll, 'Small communities with big complexities in the sphere of interaction': 52.
} 


\section{Data: Artists' books and (fan)zines}

For 'Subjective Maps / Disappearances', 37 artists presented 34 artists' books and fanzines in completely different formats, designs, techniques and styles. They (alternatively or simultaneously) illustrated found stories, documented/re-worked previous pieces (e.g. films, performances, photos) and constituted new projects of their own. Because of time constraints, I analysed one piece from each micro-area, choosing randomly but keeping in mind what I could read (Italian, English and German). Still, an analysis of all 15 books would not be possible to present here. Therefore, I used some books to provide examples and I present the analysis of one piece towards the end.

Artists' books and fanzines were chosen by the curators as a specific format for the contributions for five major reasons. First, Icelandic culture particularly values reading and the production of books. Each little village on the island has a library or a reading room which is an important meeting and recreational point. ${ }^{64}$ Second, in Iceland, the artists' book has an important tradition, especially due to the legacy of artists' like the German-Swiss Dieter Roth, who married an Icelander in 1957 and resided in Reykjavik for around a decade. Roth experimented with the book as a conceptual and exhibition space, questioning printing and reading conventions. For example, he cut the pages off for the readers to make stories of their own and used transparent coloured papers with cut-outs which could be read from both sides resulting in changing 'performances' (fig. 4). ${ }^{65}$ Similar strategies were also used by the artists on show in Iceland, who often symbolised (dis)appearance through transparency and the ambiguity of double-sided books. Icelandic artists continue experimenting with books, often distancing themselves from their Rothian use as sculptural objects and revaluing narrative. ${ }^{66}$ According to Runólfsson, these 'secondphase' artists' books escape the page and often work as 'tickets' for the readers to other worlds. ${ }^{67}$ Third, Johanna Drucker, scholar and (book) artist, argues that "the artist's book is the quintessential 20th-century artform. Artists' books appear in every major movement in art and literature". ${ }^{68}$ A visit to the New York Art Book Fair in 2010 confirmed their relevance to Canarezza and Coro. ${ }^{69}$ Fourth, there was the special

\footnotetext{
${ }^{64}$ Canarezza and Coro, On Little Constellation.

65 Roth, 2 Bilderbücher.

${ }^{66}$ Runólfsson, On Subjective Maps / Disappearances.

67 Runólfsson.

68 Drucker, The Century of Artists' Books: 1.

${ }^{69}$ Canarezza and Coro, On Little Constellation.
} 


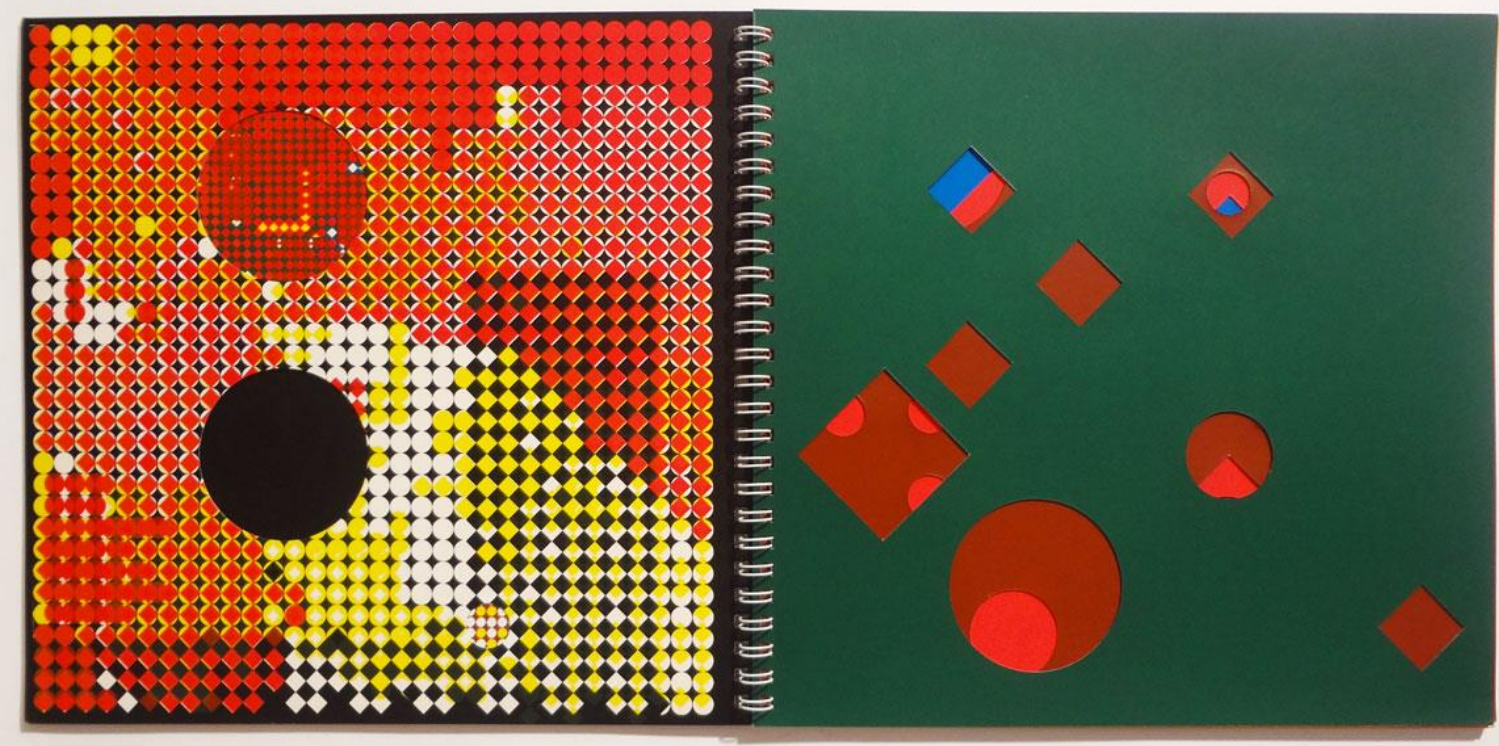

Figure 4 Roth, Dieter, 2 Bilderbücher, Vol.1, 1976.

function that the book represents as the "cultural archetype for the transmission and preservation of knowledge". ${ }^{70}$ The book can simultaneously narrate and document, the two basic functions of storytelling and mapmaking: as it was already noted, the book served, throughout the research undertaken within Little Constellation, to concretise and archive relational, dematerialised projects. Lastly, there were logistic reasons: given the big number of artists and the limited resources, the format allowed the artists to transport the works with them to Iceland. However, the choice of this format also kept away potential donors who, according to Runólfsson, did not perceive the books as full-blown artworks. ${ }^{71}$

To contextualise the use of artists' books and fanzines in the exhibition I now delve deeper into the histories and (sub)cultures of these publications.

\section{Artists' Books}

It is generally acknowledged that artists' books have a dual nature: they are simultaneously books i.e. "a set of written or printed pages attached and bound together, primarily to record information in textual or visual form"72 and artworks "collected both by libraries, and galleries and museums"73 by way of being the product

\footnotetext{
70 Canarezza et al., Subjective Maps: 6.

71 Runólfsson, On Subjective Maps / Disappearances.

72 Montero, 'Artists' Books in HE Teaching and Learning': 41.

73 Montero: 41.
} 
of artists. This duality questions the capacity of either a literary or an art-historical analysis to understand artists' books in their totality, an aspect which marks most of the discourse around this genre (see method section).

More precisely, according to Stephen Bury, artists' books are 'books or booklike objects, over the final appearance of which an artist has had a high degree of control... In practice, this definition breaks down as artists challenge it, pushing the book format in unexpected directions" 74 This and similar definitions rely on the identity of the creator: a writer could not create artists' books. However, who defines who is an artist and who is 'merely' a writer?

Moving away from ad personam definitions, Drucker adds that "not every book made by an artist is an artist's book, in spite of the old Duchampian adage that art is what an artist says it is." 75 Instead of a category, she suggests a "zone of activity" at the intersection of different practices:

fine printing, independent publishing, the craft tradition of book arts, conceptual art, painting and other traditional arts, politically motivated art activity and activist production, performance ... concrete poetry, experimental music, computer and electronic arts, and last but not least, the tradition of the illustrated book, the livre d'artiste. ${ }^{76}$

Moreover, according to Drucker, the self-conscious use of the book is a criterion of paramount importance to define artists' books. The structure of the codex should be consciously used as a space to experiment with features like sequencing, hierarchy and direction of reading as narrative/symbolic devices, an aspect which Bury also underlines: the "format and apparatus [of artists' books are] susceptible to being laid bare, made visible, parodied or ironized."77 However, Drucker argues that this consciousness was achieved only in the $20^{\text {th }}$ century and it is not traceable to any single artist/movement. ${ }^{78}$ In the end, according to all aforementioned definitions, special illustrations and/or limited editions are not enough to define artists' books. Sometimes the profession of the author is decisive, sometimes it is the outcome or the experience of the person interacting with the object which matters. Although developed

\footnotetext{
74 Bury, Artists' Books: 1.

75 Drucker, The Century of Artists' Books: 9.

${ }^{76}$ Drucker: 2.

77 Bury, Artists' Books: 3.

${ }^{78}$ Drucker, The Century of Artists' Books: 11.
} 
in different traditions and only very recently crossbreeding and revitalizing each other, ${ }^{79}$ a similar in-between situation is found in fanzines.

\section{Fanzines}

Fanzines are, according to Stephen Duncombe, "scruffy, handmade little pamphlets. Little publications filled with rantings of high weirdness and exploding with chaotic design."80 They are "non-commercial, nonprofessional, small-circulation magazines which their creators produce, publish and distribute by themselves." ${ }^{81}$ Zines circulate in a gift economy, ${ }^{82}$ they are exchanged for other zines or cheaply sold. They are often personally mailed, with hand-written addresses on personalized envelopes, including, sometimes, additional small gifts (e.g. stickers). Zine-making is a "deliberately messy, inefficient and labor-intensive," ${ }^{83}$ activity, whose material, haptic quality is arguably what keeps the genre alive and differentiates it from blog writing. ${ }^{84}$ This kind of underground, amateur, material press (e-zines exist, but are harshly criticized $^{85}$ ) lives of the community which produces, reads, and gives personal feedback on it, possibly bringing together an "embodied community." 86

The first fanzines were written in the 30 s by sci-fi fans. ${ }^{87}$ Similar publications emerged in the mid-70s around punk-rock music, which was still neglected by the mainstream music press. ${ }^{88}$ The scene diversified increasingly crossbreeding with "a long line of media for the misbegotten, ... radical pamphleteers, up through the underground press of the $60 \mathrm{~s}$, and on towards the Internet". ${ }^{89}$ In the evolution from topic-specific fan publications to the modern eclectic landscape, the 'fan-' was mostly dropped to generally talk about 'zines'. Zines present nowadays an extremely varied taxonomy, from art to music, film, sports, sex, religion, politics and many others. ${ }^{90}$ Born as ephemeral underground press and outlet for socially awkward, "self-conscious

\footnotetext{
79 Zweig, 'Artists, Books, Zines': 2, 4-5.

${ }^{80}$ Duncombe, Notes from Underground: 6.

81 Duncombe: 10-11

82 Piepmeier, 'Why Zines Matter': 231.

83 Piepmeier: 230.

84 Piepmeier: 221.

85 Piepmeier: 220-221.

${ }^{86}$ Piepmeier.

87 Duncombe, Notes from Underground: 11.

88 Duncombe: 11.

89 Duncombe: 19.

90 Duncombe: 15-17.
} 
losers," 91 the 'art' branch of the zine became a trend in exhibition catalogues ${ }^{92}$ and its sale "skyrocketed" 93 on the Internet. They landed in major art galleries, museums and fairs, including the New York Art Book Fair, where in 2010 Canarezza and Coro noticed their contemporary relevance. ${ }^{94}$ So-called 'art zines' have almost become a different genre as we can see from Thomas' ${ }^{\prime 95}$ list of recurrent features:

Created by artist, designer, or architect

The hand of the creator is evident (signed, illustrated, punched, stamped, etc.) Limited, numbered editions are large

No ISSN

No ISBN

Irregular size or shape (not magazine size)

Not particularly sculptural or dimensional

No masthead

No known publishing company

Independent publisher or art gallery (not fine press)

Available directly from creator

Available from an art bookstore or zine distributor ("distro")

Identified by the creator as a zine

Modestly priced (less than the price of a typical artists' book, but more than traditional zines)

Not usually available for trade (as traditional zines are) ${ }^{96}$

Comparing the books on exhibition with the list above, I suggest that it was mostly the art zine and its format the artists' point of reference, not the underground subcultural context described above. The format e.g. the DIY black and white photocopied booklet stayed sometimes (e.g. see the fanzine by Unn Joensen, fig. 5). ${ }^{97}$ In line with the exhibition concept, the zines were made-to-look-like ephemeral, vulnerable objects which could 'disappear'. However, the intimate socio-cultural context of reading and exchange was lost in the public setting of the exhibition. Created as artworks, art zines like the ones for 'Subjective Maps / Disappearances' must be handled with care and in no way brought home, tucked in the backpack, in the pocket of your jeans, folded in halves - all things which would mark the physical interaction of readers with their own fanzines. Although the handmade design could contribute to the feeling of being

\footnotetext{
91 Duncombe: 22.

92 Thomas, 'Value and Validity of Art Zines as an Art Form': 32.

93 Thomas: 32.

94 Canarezza and Coro, On Little Constellation.

95 Thomas, 'Value and Validity of Art Zines as an Art Form'.

96 Thomas: 30.

97 Joensen, Liv- $\circlearrowright$ Left Overs.
} 


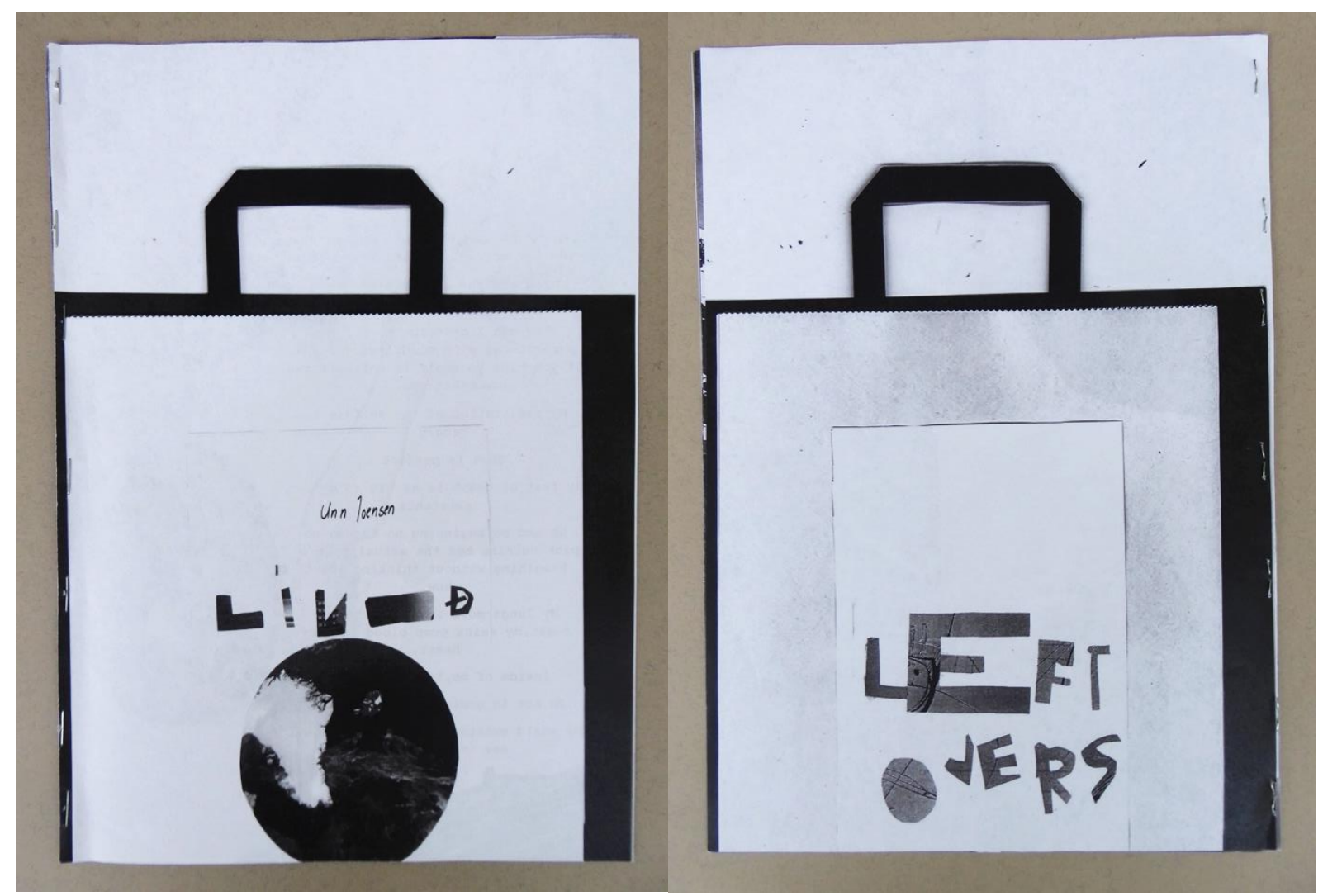

Figure 5 Joensen, Unn. Liv-ð Left Overs.

personally addressed, that wouldn't compare to the intimacy of a personally handaddressed letter, and the reader could not reply with a personal, written response (all features of traditional zines). ${ }^{98}$

\section{Notes on books, time and space}

From this excursus on the stories and cultures of the two genres of publications, I could draw a few conclusions to design the analysis. First, surely the ad personam definition of artists' books (e.g. Bury), but often other definitions as well (e.g. Drucker), would apply to any book created for the Icelandic exhibition. The works did not differ in their genre, but only in the aesthetics (e.g. layout, printing, binding, style) resembling, sometimes, art zines. For this reason, keeping in mind the symbolic value that certain formats bring with them, I will analyse and generally refer to all the books as artists' books.

Second, Bury presents three leitmotifs in the (pre)history of artists books: "their dependence on and independence of technology from lithography to desk-topping; how they relate to sound and the body; and their connection with multiplicity,

98 Piepmeier, 'Why Zines Matter': 213-215. 
modulating their relationship with a mass or élite audience."99 First, the artists worked differently with technology according to their practice: some books were completely digitally produced (e.g. photos, typed texts), in some others the 'hand' of the author is very visible (e.g. drawings, collage, handwriting). Second, the relation to body and sound is directly linked to the concept of materiality and to the analysis of rhythms, a point which underlines the usefulness of these categories in the analysis. Lastly, multiplicity was only symbolically addressed, because all the books were produced as limited editions (sometimes numbered and signed) and to be exhibited and collected by art institutions. Therefore, the concept of 'democratic multiple'100 (i.e. cheaply and easily reproducible artwork to be easily accessible for the masses against the elitist art world) did not play an important role in the production of these artists' books.

Finally, I could better understand the possibilities given by the book as a medium for artistic experimentation on issues of communication, narration and archival: "book art shares with wall art a two-dimensional plane (its pages and page spreads); it shares with sculpture a three-dimensional space (its volume); and it shares with music and narrative a fourth-dimensional temporality (its pacing, timing, sequence, and movement)."101 Therefore, the book format, when self-consciously employed, can simultaneously embody both spatial and temporal relations, ${ }^{102}$ a point which makes artists' books a particularly well-suited genre to embody mapmaking and storytelling.

\section{The catalogue and first impressions}

The first book I could look at was the catalogue of the exhibition, a thick tome printed in shades of petroleum (fig. 6). The book works as an atlas, ${ }^{103}$ recollecting excerpts of all the 34 books presented in the exhibition in a "visual labyrinth". 104 The parts are numbered, tagged with the name of the artist and sequenced by small area. Moreover, smaller pages with the same design as the cover but printed on bright yellow and green paper are scattered throughout the book. In my preliminary research, I noticed that by framing the excerpts in a common format (A4, portrait), layout (succession of tagged excerpts), paper and printing (non-bleached paper printed in shades of petroleum) all the material differences were flattening the originals to a

\footnotetext{
99 Bury, Artists' Books: 6.

100 Drucker, The Century of Artists' Books: 69.

101 Brown, 'Book Arts and the Desire for Theory': 8.

102 Macken, 'Designing with/for/through the Existing: Artists' Books and Documentation': 15.

${ }^{103}$ Canarezza et al., Subjective Maps: 6.

104 Castiglioni, On Subjective maps / Disappearances.
} 


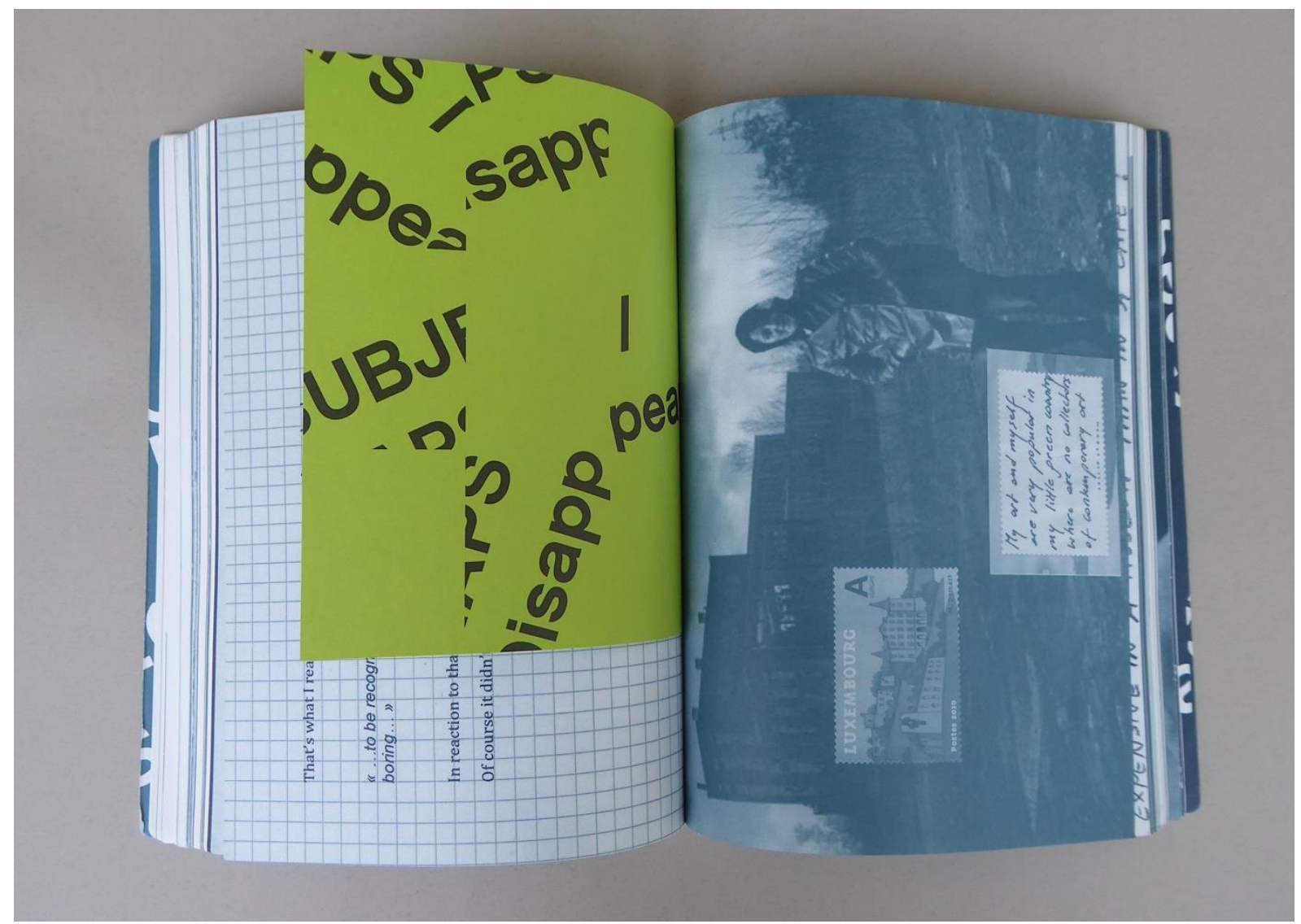

Figure 6 Canarezza et al., Subjective Maps / Disappearances.

common denominator. In this way, the catalogue achieved a unity of the extreme variety of contributions thereby creating another dimension -like lenses- to experience them more as references then parts of the originals.

I've got so well acquainted with the content of the catalogue that when I finally read the works I was really surprised. Indeed, they all had unique shapes, formats, colours, printing, bindings, styles, illustrations and possible ways of interacting with them (fig 7). ${ }^{105}$ Far from being a mere mental exercise, this experience relied on at least four senses and movement to be performed. Not only could I see the works, perceiving the colours, contrasts, masses and vectors, but what struck me were the odour, the tactile experience of the different surfaces, the sound of the different pages folding, unfolding and flipping. The papers and printed surfaces differed in thickness, texture, patination and printing technique, which I could perceive by touching them. The different papers, colours and glues had different fragrances and even though the books have been stored together for years, they didn't lose their distinctive mark. Moreover, it was always a challenge to first understand how the books would let me

105 [Selection of Artists' Books for Subjective Maps / Disappearances]. 




Figure 7 [Selection of artists' books for Subjective Maps / Disappearances].

read them (fig. 8). ${ }^{106}$ Signs of previous usage were also visible. I found little traces of dust, eyelashes, and one little piece handwritten by the author of the artists' book thanking Canarezza and Coro for their hard work (fig. 11). These observations underline the capacity of the book to record time, ${ }^{107}$ and I add spaces, in direct relation to the moment of the exhibition. This first encounter with the books shed light on the importance of the physical interaction, like folding, unfolding and turning - all actions 'producing' time and space- to understand how artists' books work and can be analysed.

As the reflections above foreshadow, in the analysis I focus on my response as a reader to the content and the signifying strategies (i.e. how the object allows making sense of it) emerging in the reading. Therefore, I work in the direction of readerresponse theory, which is "an effort to provide a generalized account of what happens when human beings engage in a process they call reading." ${ }^{108}$ This perspective underlies the focus on the narrative of the works and how this is constructed through

106 Attalidou, In the Memory of My Mother Niki Marangou.

107 Macken, 'Designing with/for/through the Existing': 13.

108 Harkin, 'The Reception of Reader-Response Theory': 411. 
rhythms. Indeed, not all books aimed at the construction of a story. Nonetheless, to make sense of the piece, the reader will mostly look for one. ${ }^{109}$ As for any other interpretative attempt, I understand that my reading is not universal.

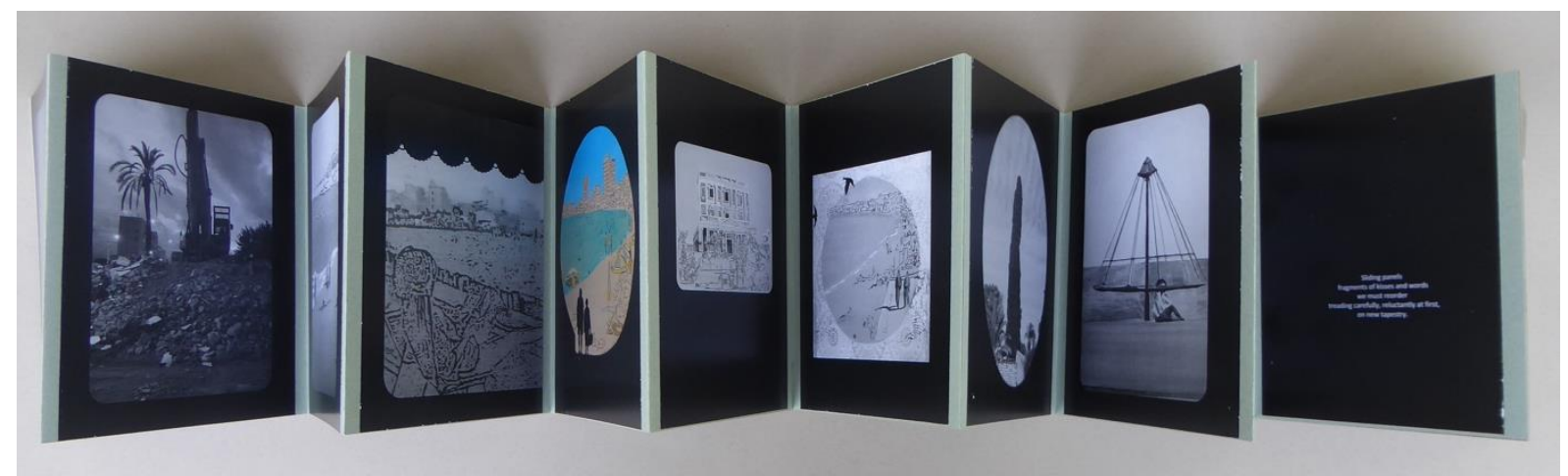

Figure 8 Attalidou, Katerina, In the memory of my mother Niki Marangou.

\section{Method: Genre-specific rhythmanalysis}

Neither a mere literary analysis nor an art-historical one, by being shaped onto parts of the dual nature of artists' books (either as books or as artworks), would suit their study as whole entities. Therefore, how should I best analyse them to look for time and space? I started from Hayles' call for a medium-specific analysis. ${ }^{110}$

Scholars have long debated the definition of 'medium' (e.g. Marshall McLuhan's technology to send messages ${ }^{111}$ ), a discourse which grows parallel to the one on 'intermediality': an umbrella and "generic term for all those phenomena that (as indicated by the prefix inter) in some way take place between media." 112 For some, the recognition of different media necessitates the understanding of their relation to other media. ${ }^{113}$ For others, "all media are mixed media"114 or under a process of "remediation" - "all mediation is remediation." 115 Without going into details, in line with other scholars, I understand artists' books as a genre ${ }^{116}$ with a "plurimedial foundation," 117 a kind of medial combination discussed in the section on intermediality.

\footnotetext{
109 Bury, Artists' Books: 3.

110 Hayles, 'Print Is Flat, Code Is Deep'.

111 McLuhan, Understanding Media.

112 Rajewsky, 'Intermediality, Intertextuality, and Remediation': 46.

113 Rajewsky: 48.

114 Mitchell, 'There Are No Visual Media': 260.

115 Bolter and Grusin, Remediation: 55.

116 Bury, Artists' Books: 4; Drucker, The Century of Artists' Books: 14; Myers and Myers, 'Opening Artists' Books to the User': 58; Montero, 'Artists' Books in HE Teaching and Learning': 38.

117 Rajewsky, 'Intermediality, Intertextuality, and Remediation': 52.
} 
Therefore, I transferred the concerns of medium-specific analysis to artists' books in a genre-specific analysis.

Hayles does not prescribe any method, but she asks to avoid assumptions inherited by disciplinary traditions. In particular, she laments that "lulled into somnolence by five hundred years of print, literary studies have been slow to wake up to the importance of media-specific analysis." 118 She denounces the dematerialization of the omnipresent Barthesian 'text'. According to her, texts "must always be embodied to exist in the world." 119 Besides in the supremacy of the content against its material form, the disregard of materiality could be understood in the standardization of printing: conventions let the readers be absorbed by the story without having to care about how to read it. ${ }^{120}$ Artists' books, instead, are often made to play with -and breakconventions. ${ }^{121}$ Such books tend to be difficult to follow and memorize because their complicated dynamics and freely associative logics often hamper the construction of coherent mental images. ${ }^{122}$ They force the reader to stop to decide how to go on and make sense of the piece. Ward Tietz frames this exercise as a rather unusual movement between the poles of reading and viewing; ${ }^{123}$ Lyn Ashby calls it 'postliteracy' because she sees artists' book as a "laboratory and home"124 for a different kind of literacy.

Specifically, Martin Sundberg argues that artists' books work in a simultaneous stabilization and destabilization: ${ }^{125}$ the different media present in the books need each other as artists' books are planned as self-contained worlds with a unique final form (i.e. stabilization). Image materials, for example, may contribute to the story in ways that are not covered by the text and that's why they must be analysed in their entirety. Nonetheless, the lack of a transparent hierarchy between the media challenges the pace of the reading, possibly destabilizing it. To shed light on how different media interact and shape the production of spaces and times in the reading, intermediality needs further explanation.

\footnotetext{
118 Hayles, 'Print Is Flat, Code Is Deep': 68.

119 Hayles: 69.

120 Sundberg, 'The Collapse of the Word-Image Dichotomy': 34.

121 Bury, Artists' Books: 3.

122 Tietz, 'Artists' Books': 18.

123 Tietz: 17, 20.

124 Ashby, 'Coming to Our Senses with a Modern Mythic Form: Postliteracy in Artistsbooks': 6.

125 Sundberg, 'The Collapse of the Word-Image Dichotomy': 34.
} 


\section{Intermediality}

I follow Rajewsky's distinction of three types of intermediality in a "narrow sense."126 These are medial transposition, medial combination and intermedial reference. The first is realized by adapting an already existing media product to a different medium (e.g. a Harry Potter film). Therefore, transposition takes into account the genealogy of the story/object. Second, there is intermediality as medial combination. In this case, different media are combined in more or less integrated ways, at times to compose genres with plurimedial configurations of their own. In this case, different medial articulations are materially present (e.g. sound and image in films). To this category belong film, opera, theatre, comics, whatever product is called multimedia or mixed media and I add, artists' books. Third, intermedial reference, means that a specific work, or genre or medium is referenced by an illusory reproduction of that specific work/genre/medium, but with the tools of the medium in use. For example, Pier Paolo Pasolini's film 'La ricotta' cites two famous Italian mannerist paintings as filmic tableaux vivants. ${ }^{127}$ The paintings are (illusorily) rendered through the means of the filmic medium. They are not physically combined with the film, but they are staged by actors in a way that makes the reference recognisable (fig. 9).

As Rajewsky points out, these three instances of intermediality are not mutually exclusive: ${ }^{128}$ a film, a combination by definition, could also be a transposition and

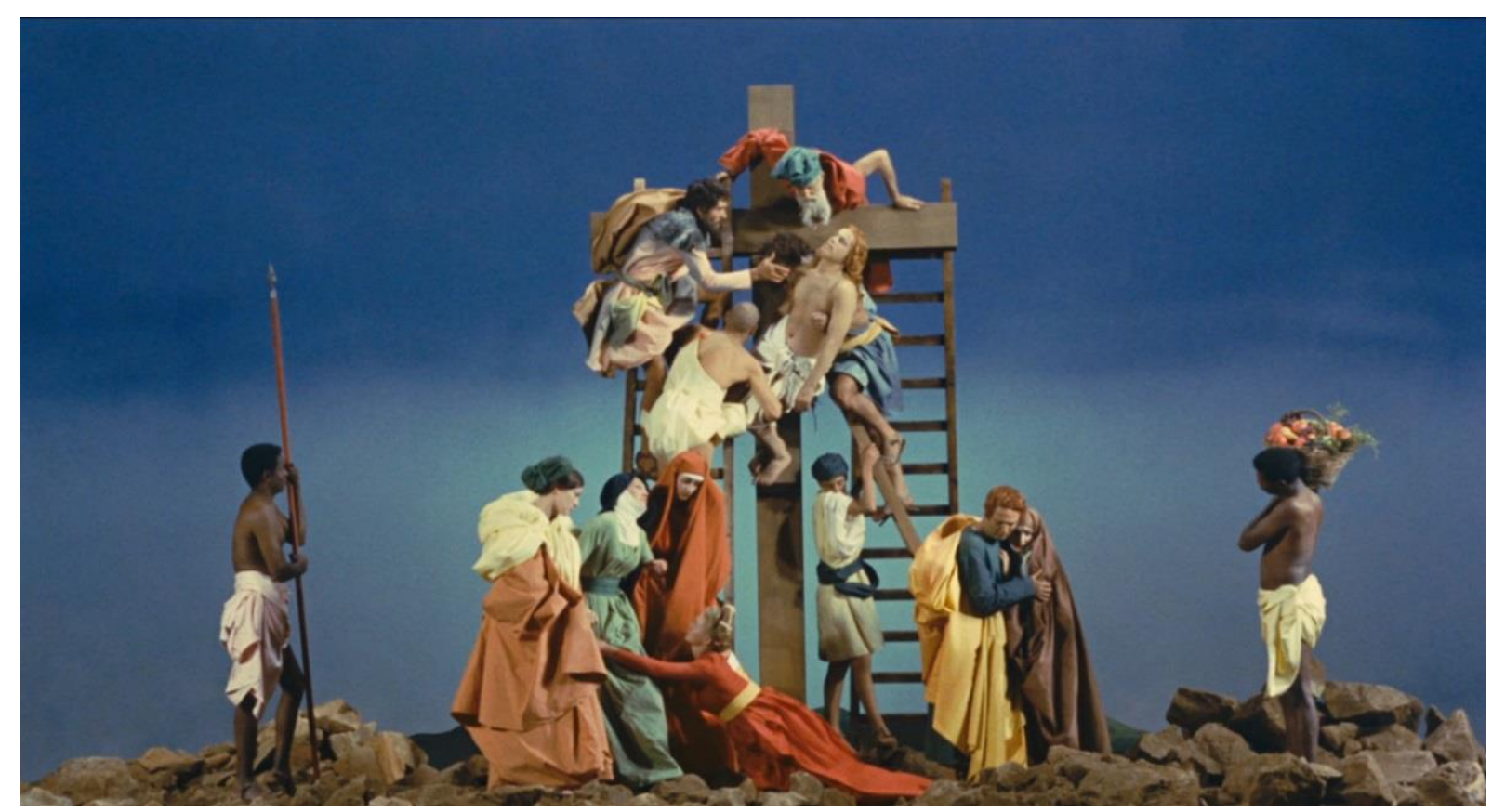

Figure 9 Pasolini, Pier Paolo, [The deposition: film still from 'La Ricotta', 1963].

${ }^{126}$ Rajewsky, 'Intermediality, Intertextuality, and Remediation': 46.

127 Pasolini, [The Deposition].

${ }^{128}$ Rajewsky, 'Intermediality, Intertextuality, and Remediation': 53. 
reference other works. Moreover, with intermediality, various layers of meaning are created by accessing different media products and interpretations. ${ }^{129}$ I suggest that the layering of meaning also entails a layering of times and spaces. Transpositions and references bridge to already existing works while the combination of different media can be employed to different narrative uses, for example to tell different storylines, to underline different aspects of a character or to trigger certain dynamics within the plot. Therefore, intermediality cannot be overlooked while analysing artists' books, especially when looking for time(s) and space(s). As a genre, they usually combine media (e.g. image and word), they often reference other works -thereby layering times and spaces- and they may be transpositions of other products (e.g. performances).

Besides the layering resulting from (inter)medial relations, I noticed other times and spaces emerging in the reading. These moments are theoretically distinguishable, but in practice, they flow into and shape each other. For example, leafing through the books, I sometimes experienced their design and production process. In Unn Joensen's ${ }^{130}$ fanzine (fig. 10) one could see the irregularity of the hand-stapled booklet,

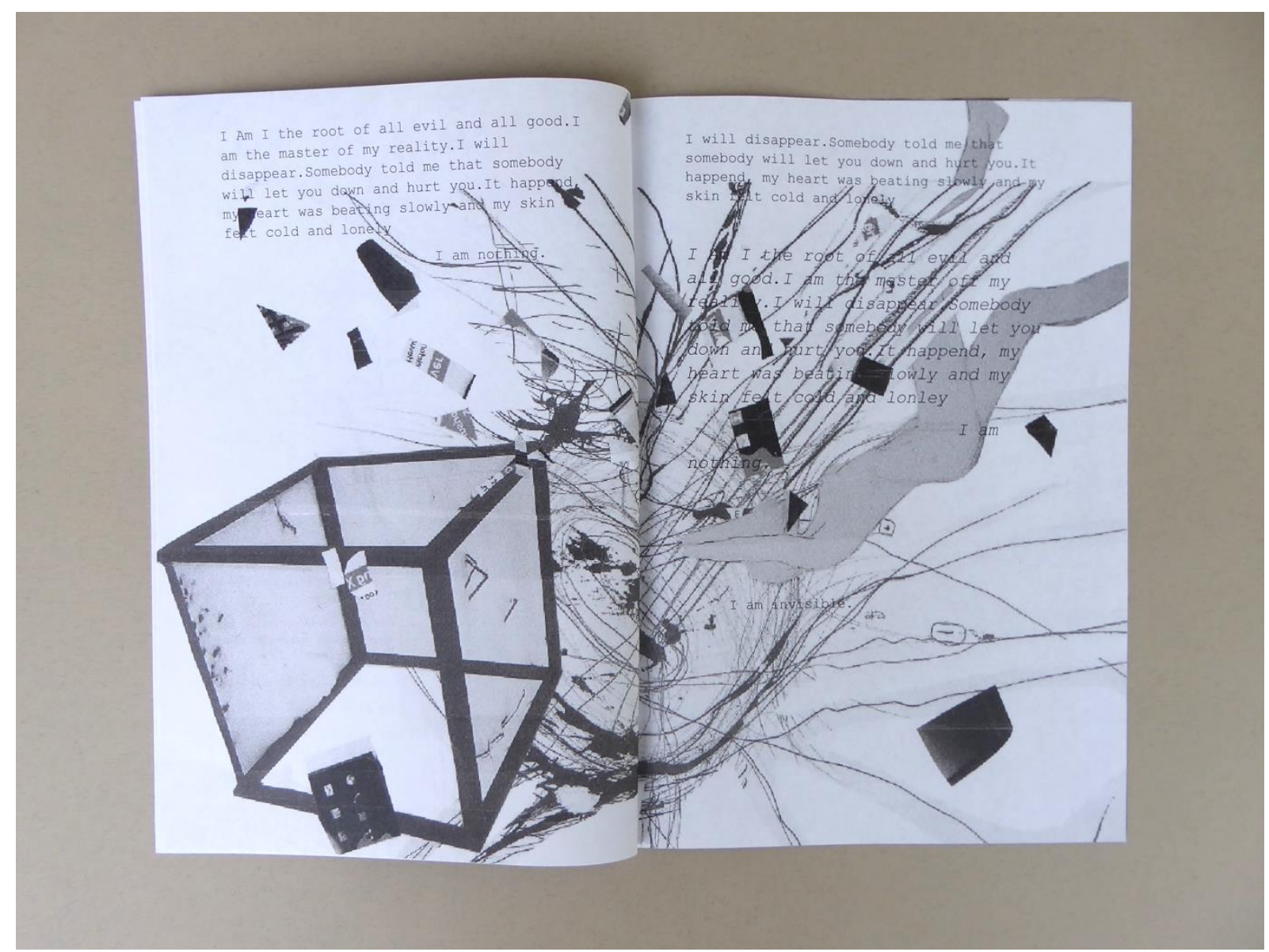

Figure 10 Joensen, Unn, Liv-ð Left Overs.

129 Rajewsky: 53.

130 Joensen, Liv-ð Left Overs. 
the edges of the photocopied collages and the strokes in the drawings. Moreover, some books gave instructions to be carried out in future/hypothetical times and places. 'Meterologies' by Nina Danino contained a script and 'ATLAS - 12 embroidery designs' by Justine Blau (fig. 11) ${ }^{131}$ presented 12 found images of skin seen from a microscope as charts for cross-stitching. The models show the typical gridded patterns outlining the colour and position of each stitch, which is numbered and coded in the legend underneath the image. The artist included suggestions for the kind of needle, fabric, threads and scissors. These instructions produce and reference times and spaces whose potential is embedded in the structure of the work even if the designs are not realised yet. In sum, all this complex layering, through intermedial relations and the embodiment of different moments like the production process and hypothetical realisation of instructions, shapes back the time and space of the reading. The fragmentation of the narrative and the interplay of different media slows down, speeds up and further entangles the reading in ways which are exampled in the following section.

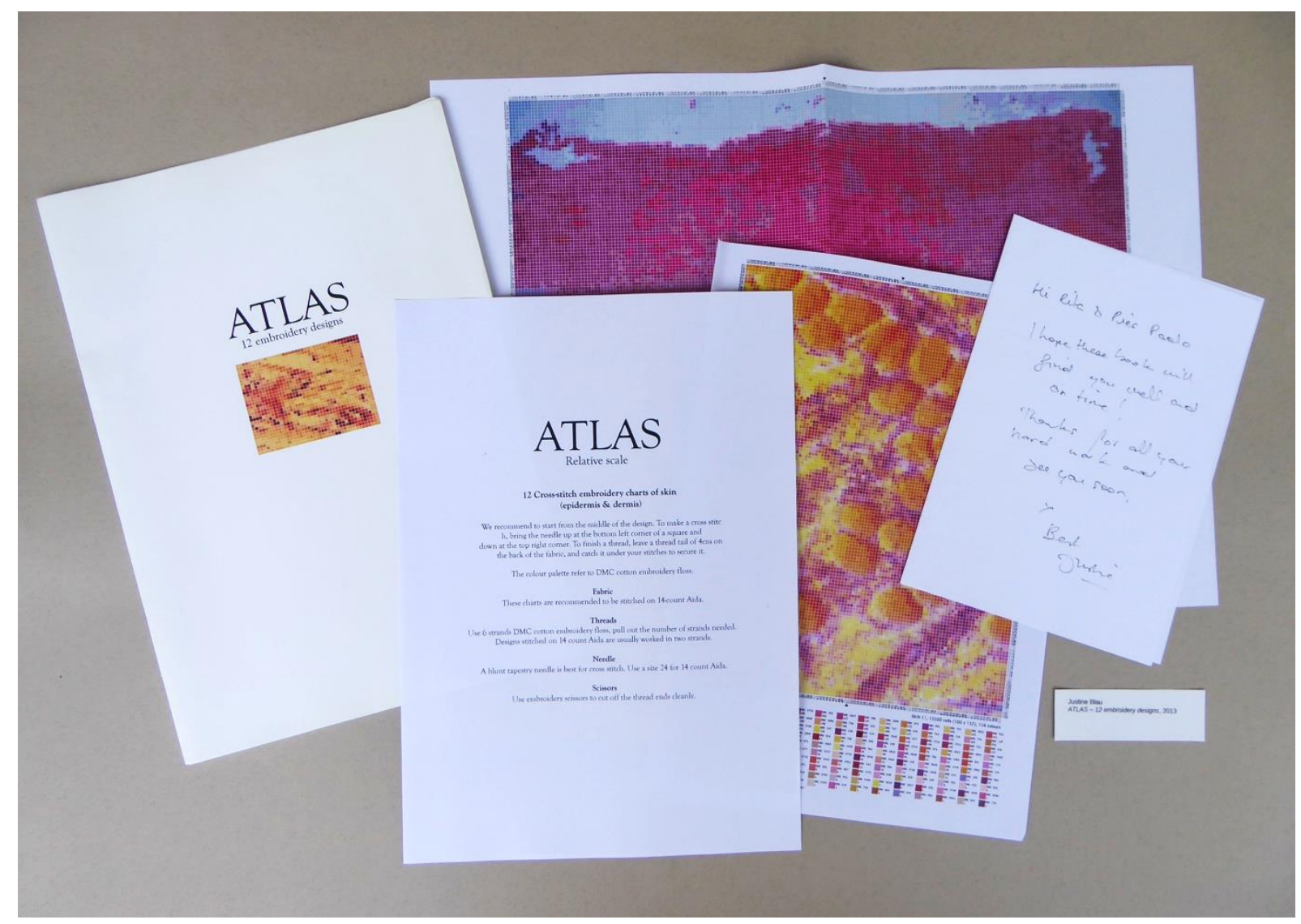

Figure 11 Blau, Justine, ATLAS - 12 embroidery designs.

${ }^{131}$ Blau, ATLAS - 12 Embroidery Designs. 


\section{Time, Space and Rhythms}

After this initial phase of understanding of how the books worked as a whole through the interaction of their different parts and references, I analysed them for rhythms. According to Henri Lefebvre, in the study of everyday life "time is distinguishable, but not separable from space"132 Time and space are not the Kantian pure universal categories of experience: "contra Kant, [Lefebvre] emphasized the historicality of their experience ... time and space could be experienced as such, and their experience was directly related to the historical conditions they were experienced within." 133 Space and time are (socially) produced through experience, they are not a priori "empty formal containers." ${ }^{134}$ Moreover, there is no hierarchy between time and space as it had often been the case. For example, Marxism mostly privileged time over space, history over geography. ${ }^{135}$ Similarly, one could argue that literary analysis privileged time as analytical category (e.g. the classical story time vs. discourse time) and art history focused on space (a specific label had to be coined for so-called 'time-based arts').

According to Lefebvre, time and space come together in rhythms: "everywhere where there is interaction between a place, a time and an expenditure of energy, there is rhythm."136 These three elements are the constituents of a dialectic analysis. However, in contrast to the classical Hegelian thesis, antithesis and synthesis, there is no synthesis for time, space and energy. ${ }^{137}$ They come together in rhythms, but they stay distinguishable.

Lefebvre does not provide a method for rhythmanalysis. He only defines its main principles, like repetition and measure: "No rhythm without repetition in time and in space, without reprises, without returns, in short without measure [mesure]."138 Repetition always comes with difference. Indeed, the former without the latter (i.e. absolute repetition, $A=A$ ), "is only a fiction of logical and mathematical thought ... Not only does repetition not exclude differences, it also gives birth to them; it produces them." 139 Repetition can be cyclical or linear. Cyclicality and linearity "separate out under analysis, but in reality interfere with one another constantly." 140 In sum,

\footnotetext{
132 Lefebvre, The Production of Space: 175.

133 Elden, Understanding Henri Lefebvre: 185.

134 Elden: 185.

135 Elden: 185-186.

136 Lefebvre, Rhythmanalysis: 15.

137 Lefebvre: 12.

138 Lefebvre: 6.

139 Lefebvre: 7.

140 Lefebvre: 8.
} 
rhythmanalysis accounts for rhythms (time, space and energy) in the cyclical and linear repetition -and difference- through time and space:

Time and space, the cyclical and the linear, exert a reciprocal action: they measure themselves against one another; each one makes itself and is made a measuringmeasure; everything is cyclical repetition through linear repetitions. A dialectical relation (unity in opposition) thus acquires meaning and import, which is to say generality. ${ }^{141}$

The dialectic triad time-space-energy brings me back to the concept of materiality as an emergent property. I suggest that like the artists' books as such, their rhythms cannot be studied without some form of interaction with them. Time and space, in everyday life as much as in art, cannot be understood as motionless 'things' in themselves. That's why Lefebvre frames his rhythmanalysis as a critique of "thingification (reification)". ${ }^{142}$ According to him, the (philosophical) work which already criticised the stable, static 'thing' "in the name of becoming, of movement, of mobility in general" 143 has not gone far enough. The answer to thingification should be the analysis of how phenomena are produced in rhythms.

Leaving the ontology of Lefebvre's philosophical debate, I will apply the study of rhythms to the artists' books, with a focus on the following categories:

- Cyclical \& linear

- Repetition \& difference ${ }^{144}$

and properties:

- Eurhythmia,

- Arrhythmia

- Polyrhythmia ${ }^{145}$

Drawing on corporeal rhythms, these concepts can be applied to other fields, as Lefebvre explicitly saw rhythms everywhere where time, space and energy came together. Besides the affinity of research aims of Lefebvre and Little Constellation's research into everyday life, rhythmanalysis speaks especially to the use of subjective maps in the project: the 'maps/stories' produced by the artists do not refer to universal temporal or geographical coordinates. The spatio-temporality of the works and their

\footnotetext{
141 Lefebvre: 8.

142 Lefebvre: 3.

143 Lefebvre: 3.

144 Lefebvre: 9.

145 Lefebvre: 16.
} 
rhythms are not pre-given and they are also not merely a creation of the reader, because their instantiation and signification are intertwined. Instead, they emerge "in the interplay between the text as a physical artifact, its conceptual content, and the interpretive activities of readers and writers." 146

\section{Analysis: Times, Spaces and Disappearances}

\section{Rhythms in the selection of books}

The following section exemplifies the aforementioned categories and properties. These are by no means unique and mutually exclusive. Other artists' books I analysed, whose stories cannot be presented here, created similar rhythms and the categories themselves can easily merge and overlap (e.g. cyclical and linear repetition).

\section{Repetition \& difference}

Generally, any codex-like object shows the repetition of pages as a basic measure. The repetition does not lie only in their stapling, but also in the interaction with the reader which emerges in their turning. Moreover, with each page, the reader has a different understanding of the totality of the work. In this sense, the turning is a repetitive movement which is always different. Additionally, the sequencing of different kinds of pages can also establish rhythms through repetition and difference. For example, Pierre Portelli (fig. 12) in his 'Stradamerkanti' ${ }^{147}$ (merchants' street) alternates photo-pages to white pages. The former are full-page pictures, printed on thick, glossy paper, showing the inscriptions scratched through the centuries on the walls of the merchants' street in Valletta (Malta). The latter are made of non-bleached coarse paper with debossing (i.e. permanently impressed) interventions which remind of the scratchings. Inside, two white pages, one with a debossed floor plan of the street and the other with the inscription 'STRADAMERKANTI' (where letters are alternatively missing e.g. ST ADAMER ANT), are followed by first two, then four, then three photo pages. After the last three, two pages with four rows of five photos are printed on the

\footnotetext{
146 Hayles, 'Print Is Flat, Code Is Deep': 72.

147 Portelli, STRADAMERKANTI.
} 


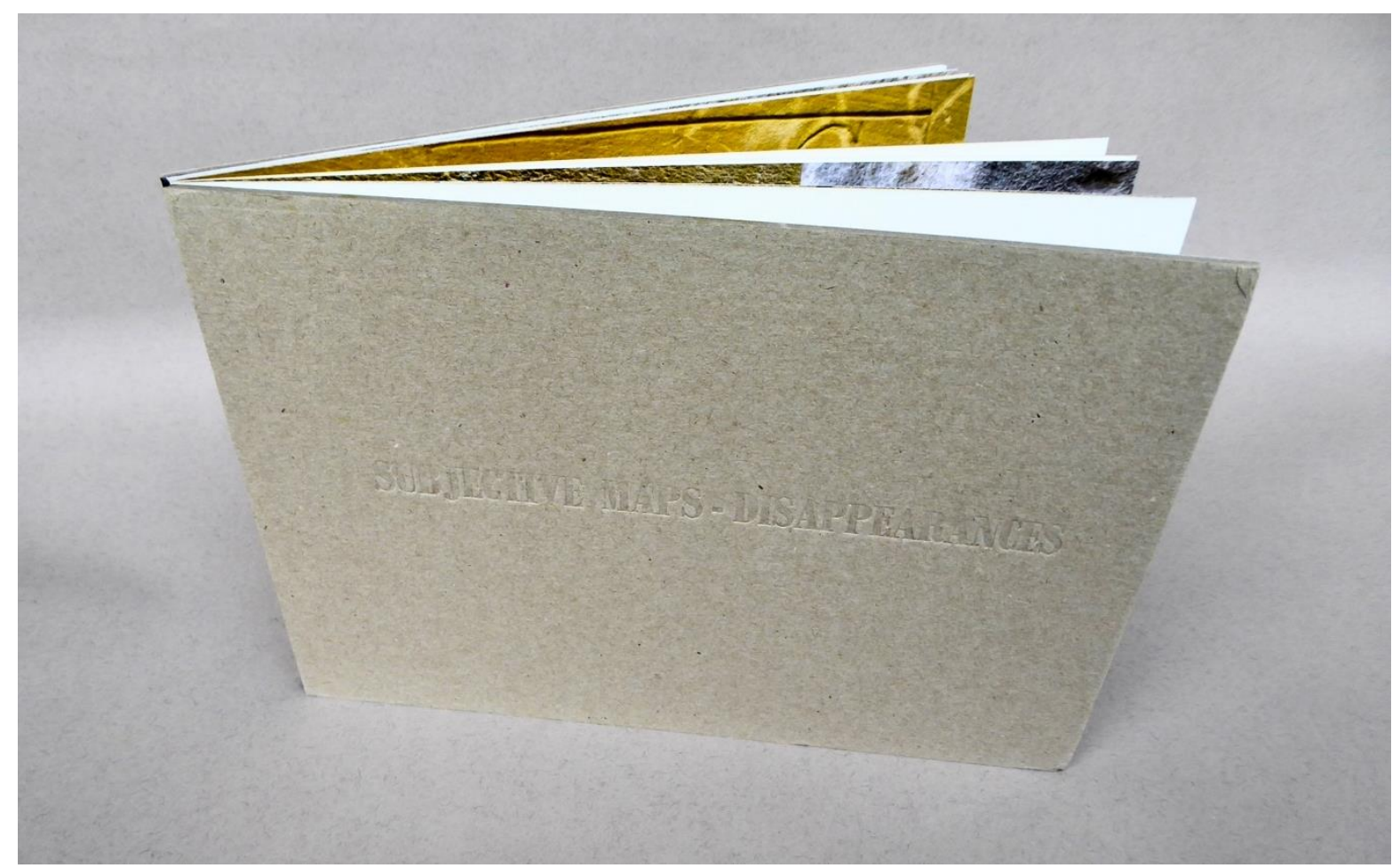

Figure 12 Portelli, Pierre, STRADAMERKANTI.

same glossy paper. In contrast to Le Ruez's work ${ }^{148}$ (fig. 13), where Cromático translucent light blue or orange sheets are folded together in the signature (folded section) ending up in specular positions, Portelli's sequence is not symmetrical. The

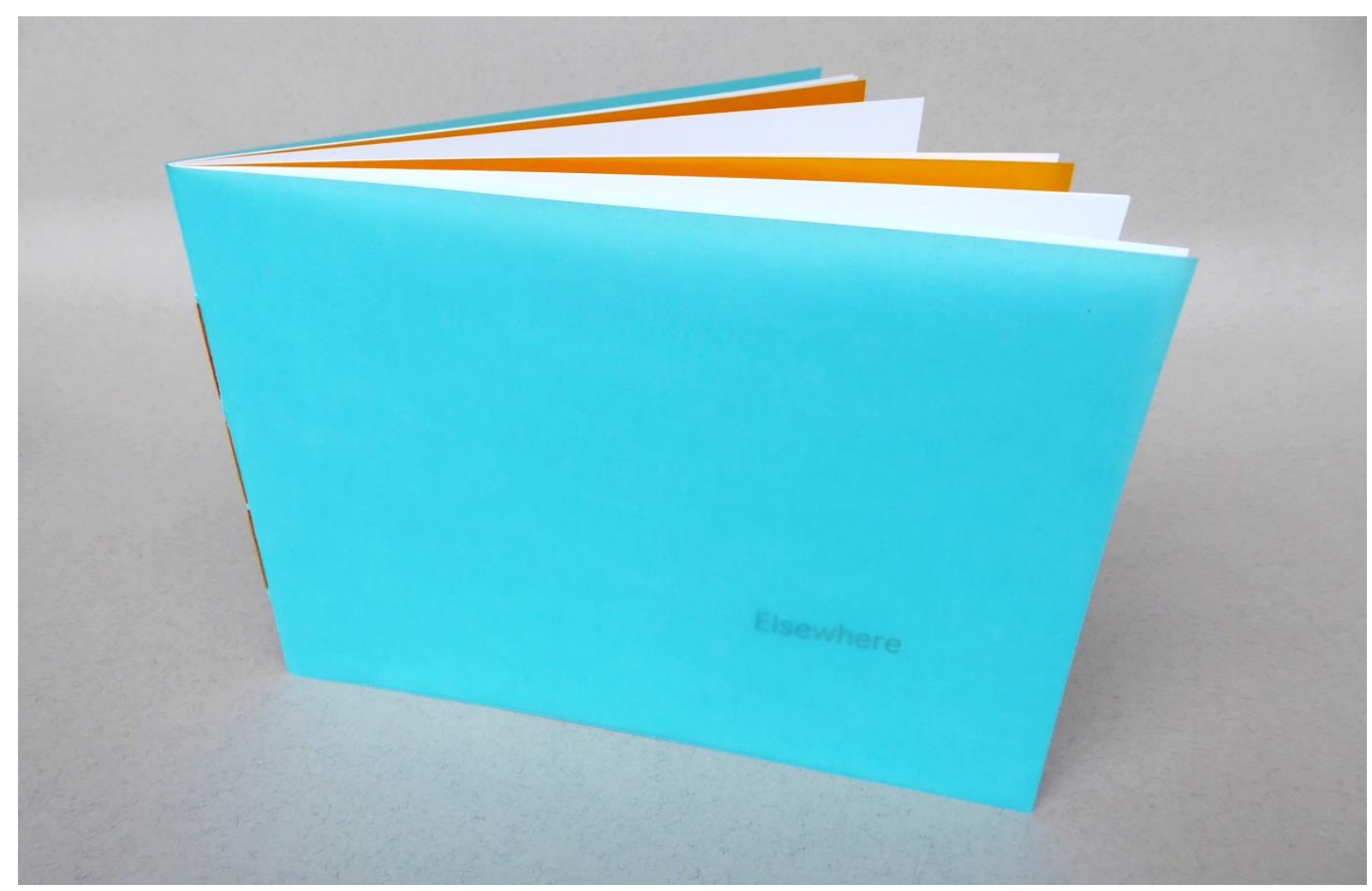

Figure 13 Le Ruez, Simon, Elsewhere.

148 Le Ruez, Elsewhere. 
pages are individually glued to the back, which allows the artist to play more with their order. He can speed up its rhythms by putting more and more pictures until they become almost endless rows, repeating a cyclical but ever-changing constellation of signs which are written, overwritten and washed or scratched away with time, like on the merchants' street.

\section{Cyclical \& linear}

Maybe the clearest example of an intertwining of the cyclical with the linear is the structure of 'Disappearance' by Teodora Nikcević (fig. 14). ${ }^{149}$ The rather thick, perfectly bound book can be read from both ends. The cover is the same on both sides, a fact which puzzled me on my search for the 'right' way to read it. The book plays with the sequence of the rainbow shadows. On each end, seven monochrome pages show all the colours (i.e. violet, indigo, blue, green, yellow, orange, red). The middle part is composed of transparent sheets onto which cut-outs of photos, including previous works by the artist, are printed out in black and the shades of the rainbow, starting from

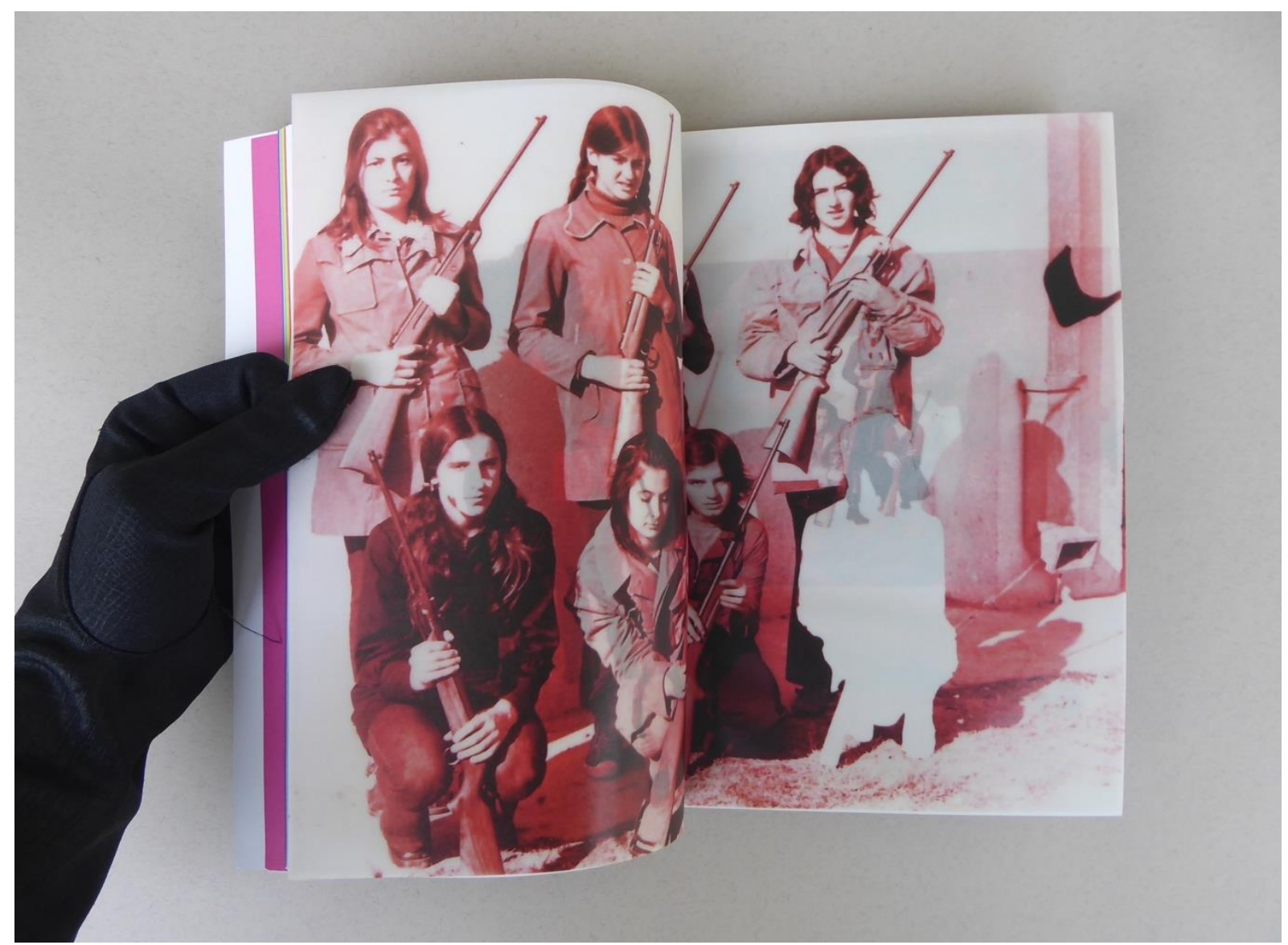

Figure 14 Nikcević, Teodora, Disappearances.

${ }^{149}$ Nikcević, Disappearances. 
purple (or red) to get to red (or purple) according to the direction of reading. The use of transparent paper is designed to engender different combinations according to the direction of reading, shedding light on the turning of the page as a discovery, as addition or subtraction, appearance or disappearance of elements through movement. All these elements show how the linear and the cyclical are indistinguishable in such a book: the end is also the beginning, but still one possible ending in itself.

\section{Symphonies in the books: eurhythmia, arrhythmia and polyrhythmia}

As in everyday life, where many rhythms coexist, in the books I could find regularity, irregularity and interplay in their multiple rhythms. Starting from Lefebvre's medical terminology, such as eurhythmia (i.e. harmonious beat), arrhythmia (e.g. anomalous beat) and polyrhythmia (multiple rhythms) I now apply it to the books.

\section{Polyrhythmia}

Inspired by the polyrhythmic relation between the various bodily organs, I thought about the simultaneous presence of different rhythms mostly in terms of (inter)medial references. In the books I examined, the rhythms of the original works -whether performances or performances turned into video- were juxtaposed to the rhythms of the booklet. For example, 'Lost Crown' (fig. 15) by Agnes Roux, ${ }^{150}$ is a performanceturned-video-turned-fanzine shot at the harbour in Monaco and below its waters. With this action, the artist wanted to explore these spaces starting from what her psychologist called her syndrome of the "princess who has lost her crown." 151 For this reason, she worked with Mimoza Koike, principal dancer of the Monte-Carlo Ballet Company, and Pierre Frolla, Monegasque world champion of freediving. The princess (Koike) was filmed nobly walking in her pointe shoes along the harbour covered in a dark mantel and throwing a big crown into the water. The abyssal knight (Frolla), a renowned "adventurous soul" 152 was given a treasure hunt map to find the lost crown. Throughout the selected stills one can feel the cinematic reference to another time and space when the film was performed and recorded above the ground, with aerial filming and underwater videography. In this case, the distance between the time and space of the video/performance and its documentation (the fanzine) is established in the first

\footnotetext{
150 Roux, Lost Crown.

151 Roux.

152 Roux.
} 


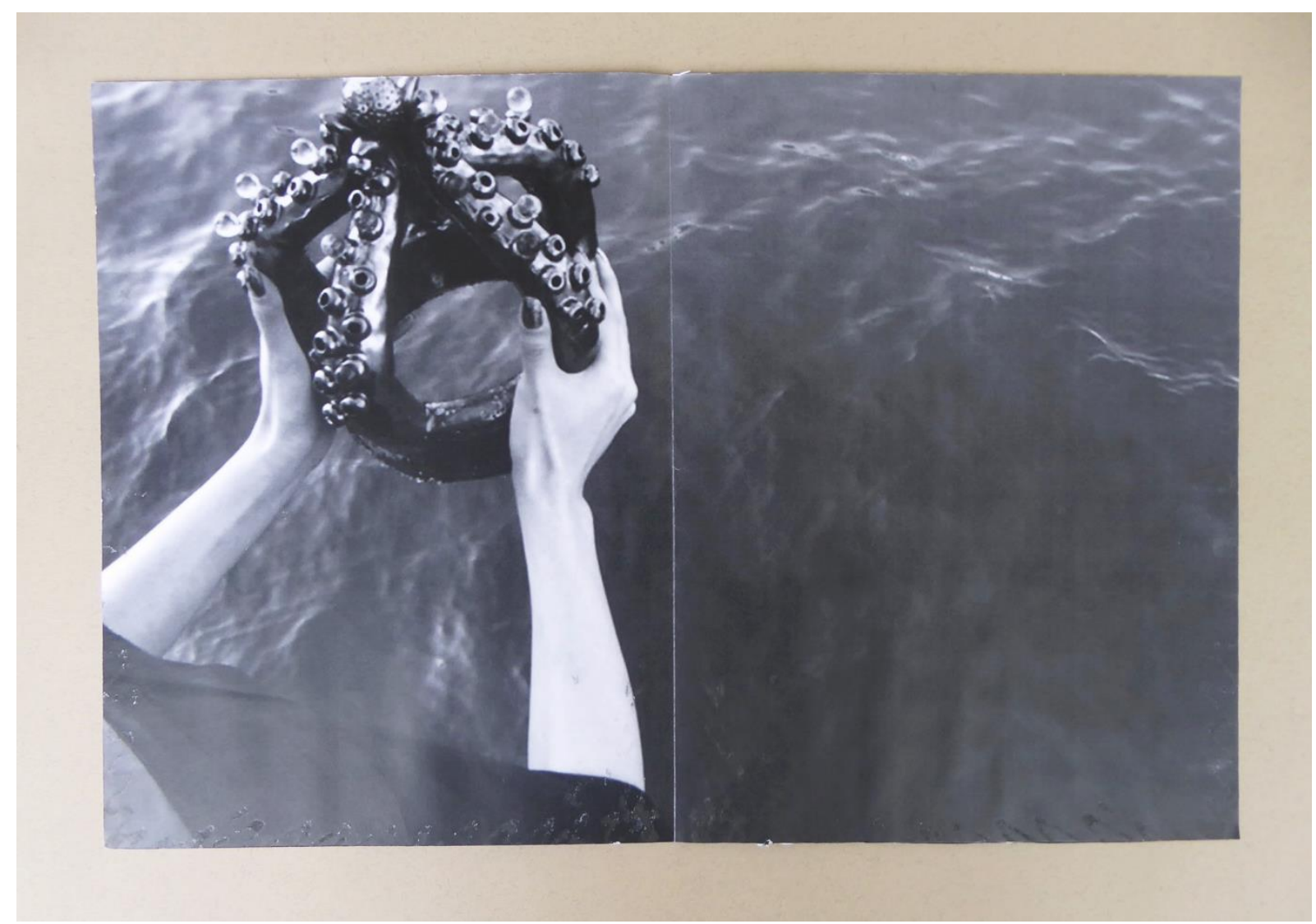

Figure 15 Roux, Agnès, Lost Crown.

spread where one finds a description of the project, a timeline and a short autobiography. Therefore, multiple rhythms are at work simultaneously in the transposition from a video of a performance into a fanzine.

\section{Eurhythmia}

Starting from the broader medical definition ("harmonious body relationships of the separate organs"), ${ }^{153}$ I understand eurhythmia as a harmony (often given by a set hierarchy) of the various signifying systems used in the work. For example, the book 'All at sea' by Eric Snell, ${ }^{154}$ not only allows unfolding in a wave-like shape (fig. 16), but the paragraphs describing the project are also written following the undulatory movement represented in the photo underneath. This wave-like effect is achieved by variation of font sizes, capitalization of letters and especially the position of the new lines: the new paragraph rarely starts back at the left edge of the page. Instead, it mostly continues in the same area (slightly before or after) where the previous paragraph ended, just one line below. This attention to the movement of the sea,

\footnotetext{
153 'Eurhythmia'.

154 Snell, All at Sea.
} 


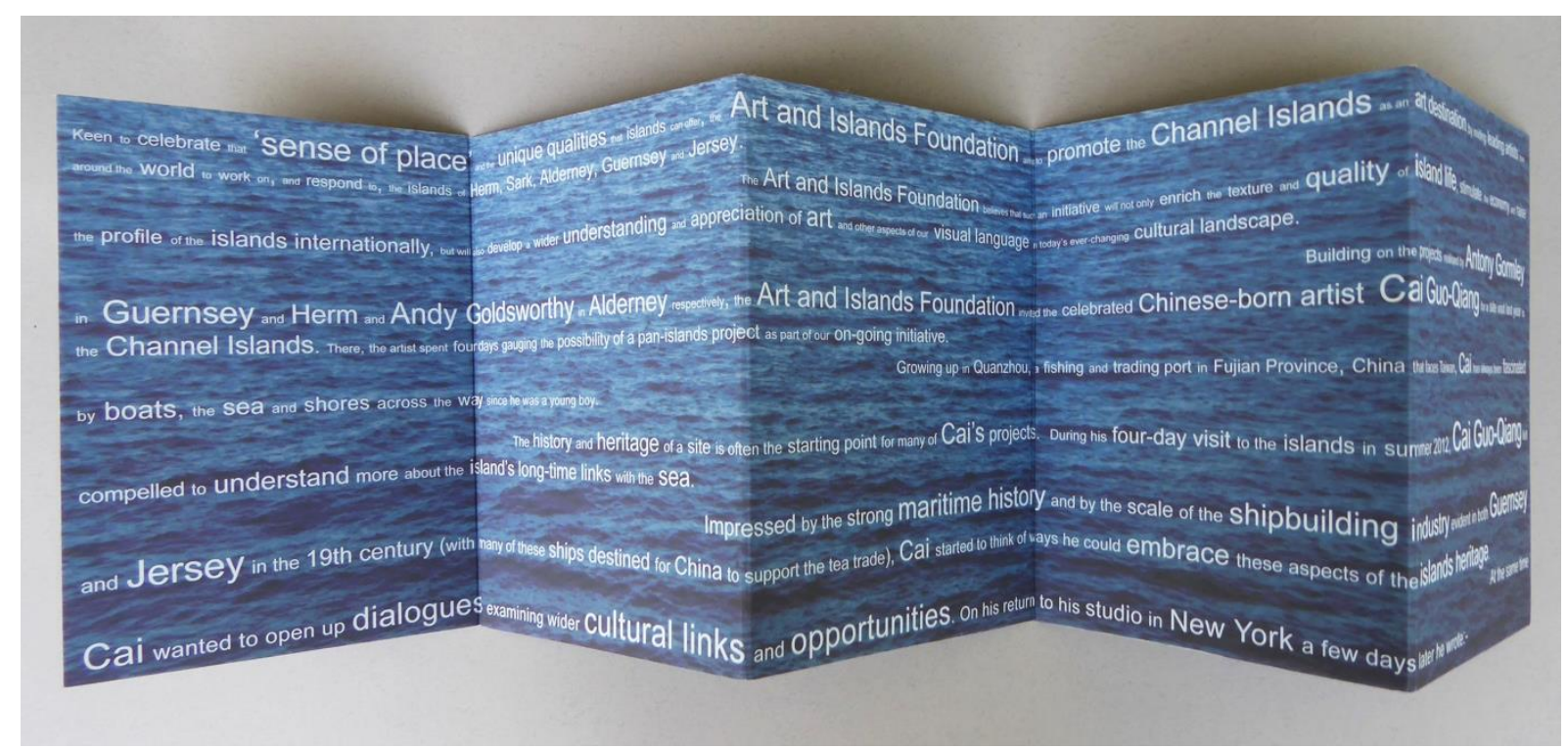

Figure 16 Snell, Eric, All at sea.

showed by the picture, embodied by the paragraph written on top of it and the overall shape of the book, shows harmony between different media: they support, complete and enhance each other still maintaining distinct qualities.

\section{Arrhythmia}

If eurhythmia denoted a harmonious relationship, arrhythmia stands for an inharmonious one. As it was already mentioned, in artists' books image and word (or any other signifying system) may follow different rhythms or even tell different stories: "oscillating between viewing and reading disrupts the textual space and changes our interpretive rhythms." 155 The divergence of different media was visible in the "the night people' (Das Nachtvolk) by Martin Walch. Once upon a time, in the night, according to the Liechtensteiner folktale, ${ }^{156}$ restless souls roamed in a long procession around the village, knocking on the windows to ask in. The rumour was that at the end of the queue one could see the figures of the people who were going to die. One night a lady convinces her husband to have a look outside because she wanted to tell the neighbours. However, he sees himself at the end of the procession and dies falling down the hayloft. In the artwork, the text has a leading role because it is written out as a coherent, self-contained story (i.e. the text by Dino Larese). ${ }^{157}$ The pictures have a secondary, albeit very important role: they build tension by interfering with the pace of the text. For example, in the most exciting parts of the story, images build suspense

\footnotetext{
155 Tietz, 'Artists' Books: Between Viewing and Reading': 18

156 Larese, 'Das Nachtvolk'.

157 Larese.
} 


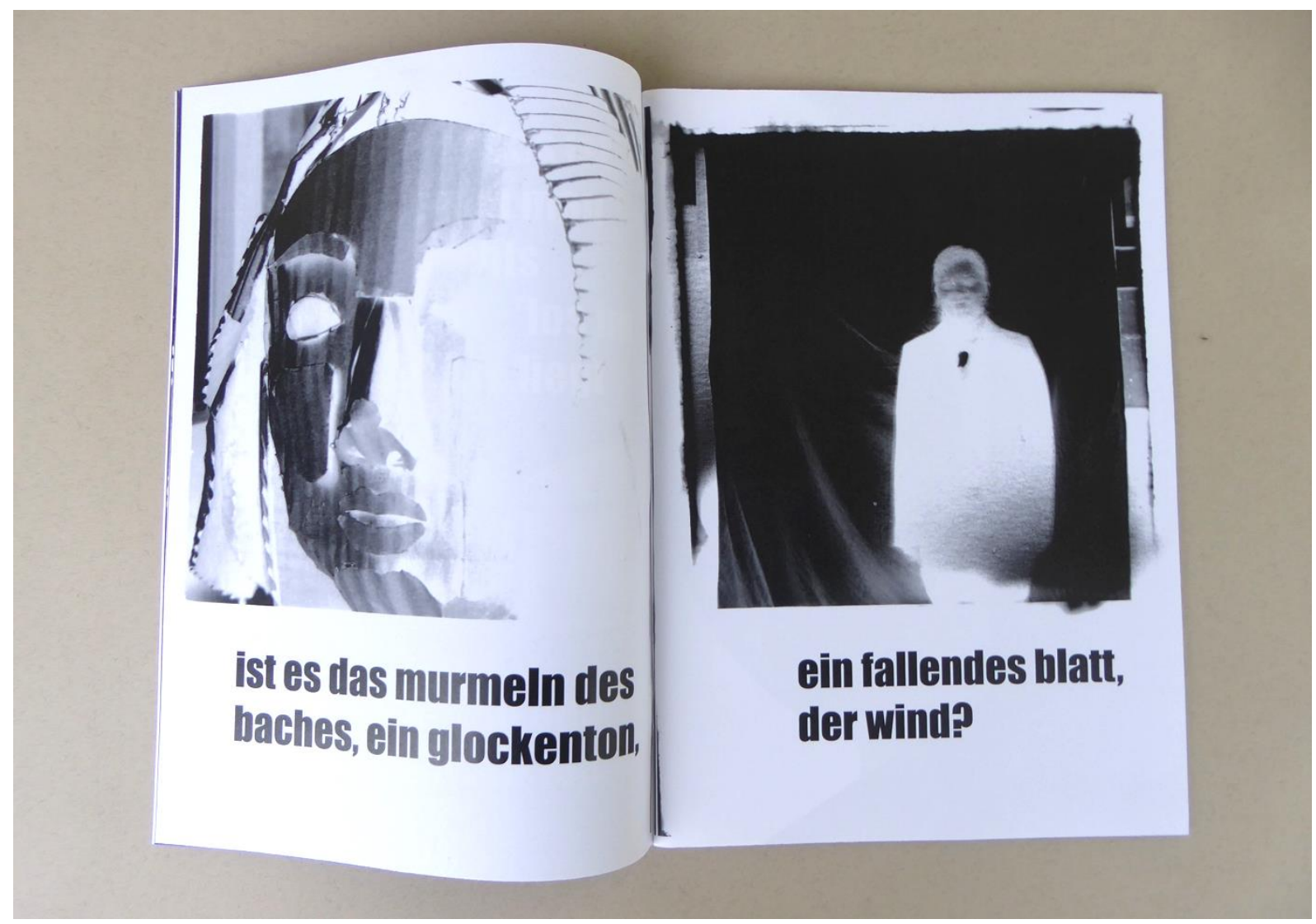

Figure 17 Walch, Martin, Das Nachtvolk.

by slowing down the textual narration (e.g. a text-free double spread). Moreover, the images often anticipate what the written text still has to tell, thereby constructing visual premonitions. For example, even before the night people is introduced, a cardboard mask, which will come back as a representation of the people, is already shown. Indeed, the whole atmosphere built by the black and white pictures (often negatives to simulate a night view), photocopied on regular paper, creates a very tense and horrorlike setting right from the start. These differences in rhythms (e.g. anticipation) break the linearity and harmony of the story told by the written text.

\section{A genre-specific rhythmanalysis}

Bringing together the aforementioned points, I engage in a genre-specific rhythmanalysis. I examine Canarezza and Coro's 'Salon Devolution / Short stories of non-independence, ${ }^{158}$ which the artists call a fanzine. Indeed, keeping in mind that in the exhibition, fanzines mostly resembled art zines, one could see many of Thomas' features in the book. For example, the book has "no ISBN; no known publishing

${ }^{158}$ Canarezza and Coro, Salon Devolution / Short Stories of Non-Independence. 
company; irregular size or shape; no masthead." 159 Moreover, it is not available for trade and not particularly sculptural. ${ }^{160}$ Canarezza \& Coro's piece is an independently printed (full colour on glossy paper with a slightly thicker grammage for the cover), saddle-stitched booklet which was cut a few millimetres smaller than an A4. The book is mostly covered in photographs/video stills, it was digitally elaborated and each copy was numbered and signed by the authors.

In the work, I recognized a visual and a narrative measure (basic unit). Visually, the book was mostly designed to work from spread to spread, with pictures often completely covering and/or crossing adjacent pages. Moreover, elements on the facing pages dialogue with each other. For example, Piazza Garibaldi in the historical centre of San Marino is represented both on page 6 and 7 (fig. 18). On the right, there is a child intensely staring at the viewer while holding munitions. The black and white photo was taken around August $1944 .{ }^{161}$ On the left, in colours, the same square is photographed in 2013, complete with tourists and souvenir shops. This juxtaposition maps the different social production of space and time at the same geographical



Figure 18 Canarezza \& Coro, Salon Devolution / Short stories of non-independence, p. 6-7.

159 Thomas, 'Value and Validity of Art Zines as an Art Form': 30.

160 Thomas: 30.

${ }^{161}$ Canarezza and Coro, On 'Salon Devolution / Short stories of non-independence'. 
location. A completely different atmosphere characterises the two pictures: on the left, the tourists are strolling from window to window, probably feeling safe and completely unaware of the history of the place. By contrast, the boy on the right may have lived through the horrors of the second world war and survived the bombings in the tunnels of the electric railway with other thousands of refugees. Notwithstanding its neutrality, San Marino was bombed by the Allies in 1944 (historical pictures at p. 2-5 of the fanzine). The boy holds munitions, but he seems unsure whether to trust the foreigner in front of him, probably a photo reporter of the English army or, by extension us, the viewers. This composition, using the whole spread as a stage and visual unit, plays on repetition and difference in time and space, leaving the reader to compare the crude transparency of the boy's already adult gaze ${ }^{162}$ with the triviality of the souvenir shops.

The narrative unit mostly develops around one research project over more spreads, crossing different times and spaces, which are 'told' mostly through pictures. For example, the hairdressers' project (i.e. a research project started by Canarezza in 1998 and developed around the social relevance of hairdressers and hairdressing in various communities) was presented in various stages, including her research in Japan on the traditional hairstyles (1998-1999) and the mapping of all hairdressers in Iceland with Coro (2009; fig. 19). The reference of previous projects creates layers of times and spaces which are all channelled back into the fanzine. Back to intermediality, I would avoid talking about transpositions as the book in its entirety does not replicate any previous artwork. However, the work references earlier projects in its own medial means (i.e. intermedial reference). Moreover, little inserts of regular paper (fig. 20) are stapled into the book with short texts, thereby mixing media. These texts, together with the index on the back cover, provide entry points into the symbolic realm of the places shown in the book. Following trade-offs like the electric railway, built in the end of the 1920s instead of an independent radio and bombed during WW2, ${ }^{163}$ a broadcasting service was granted to San Marino only in 1987, but as the artists comment, it is a "spaceship tied to the ground". ${ }^{164}$ For the reader not well acquainted with Sammarinese history, it would be hard to understand the relation between the radio, the railway and the bombings without the written texts.

\footnotetext{
162 Canarezza and Coro.

163 Piccioni, 'Il Viaggio Interrotto: La Ferrovia Elettrica Rimini-San Marino'.

164 Canarezza and Coro, Salon Devolution / Short Stories of Non-Independence.
} 


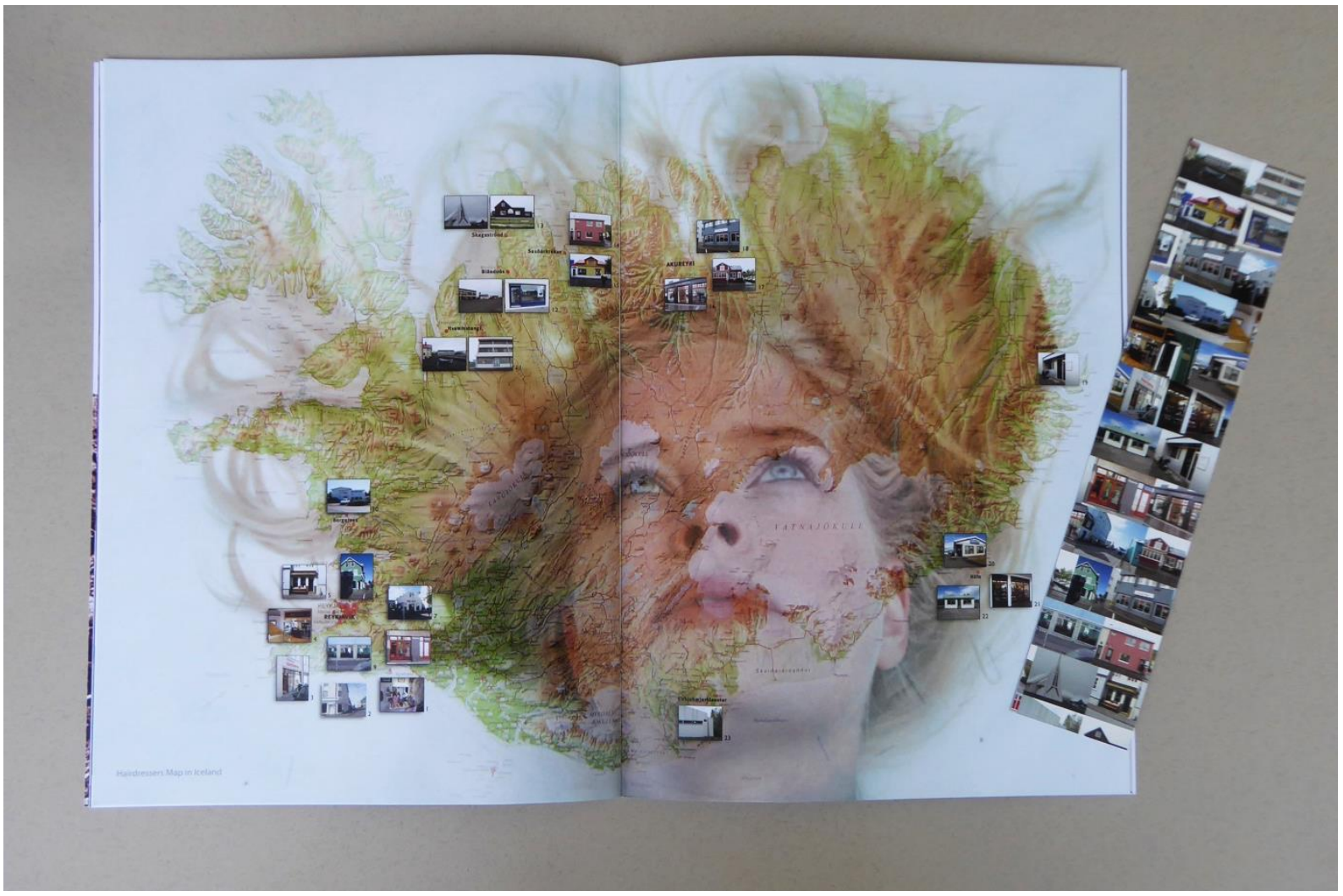

Figure 19 Canarezza \& Coro, Salon Devolution / Short stories of non-independence, p. 14-15.



Figure 20 Canarezza \& Coro, Salon Devolution / Short stories of non-independence, p. 4-5. 
In the book, the narrative units i.e. research projects, are mostly associatively juxtaposed without trying to develop any linear story. Films, performances and actions are referenced through photographic documentation to become, together, a different statement. The fragmentation resulting from the absence of a linear narrative or hierarchy, variously mentioned in this thesis, lays the hermeneutic cycle bare, forcing the reader to leaf through the book over and over again. Looking for a narrative, the reader seeks patterns and continuities which the book deliberately breaks. For example, the relation between 'Rite of passage' (fig. 21, right), showing a full-page picture of Coro as if run over by a car at a bus stop on the highway, and the composition of pictures of 'Salon Devolution' and 'Talisman to Heal Headache' (fig. 22) on the following page, is understandable only as a collection of different short stories on a common macro-theme: 165 the narration of practices and places through interventions which re-work them in personal terms. The Moroccan talisman had been studied by Canarezza in 2003-2005 by reproducing and wearing it (as she did with the Japanese hairstyles). Similarly, Coro intervened in a real situation (the bus stop had just been

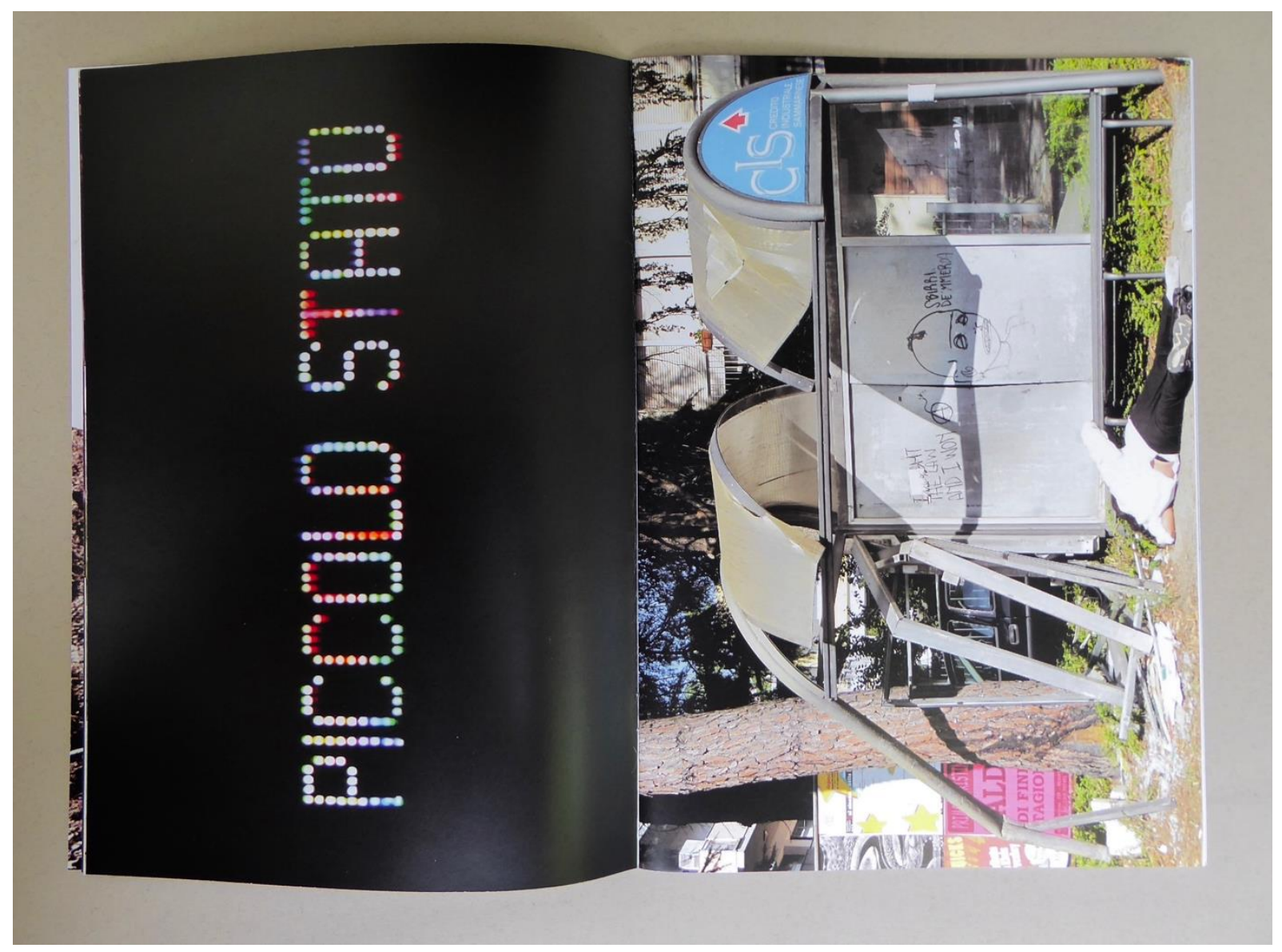

Figure 21 Canarezza \& Coro, Salon Devolution / Short stories of non-independence, p. 8-9.

${ }^{165}$ Canarezza and Coro, On 'Salon Devolution / Short stories of non-independence'. 


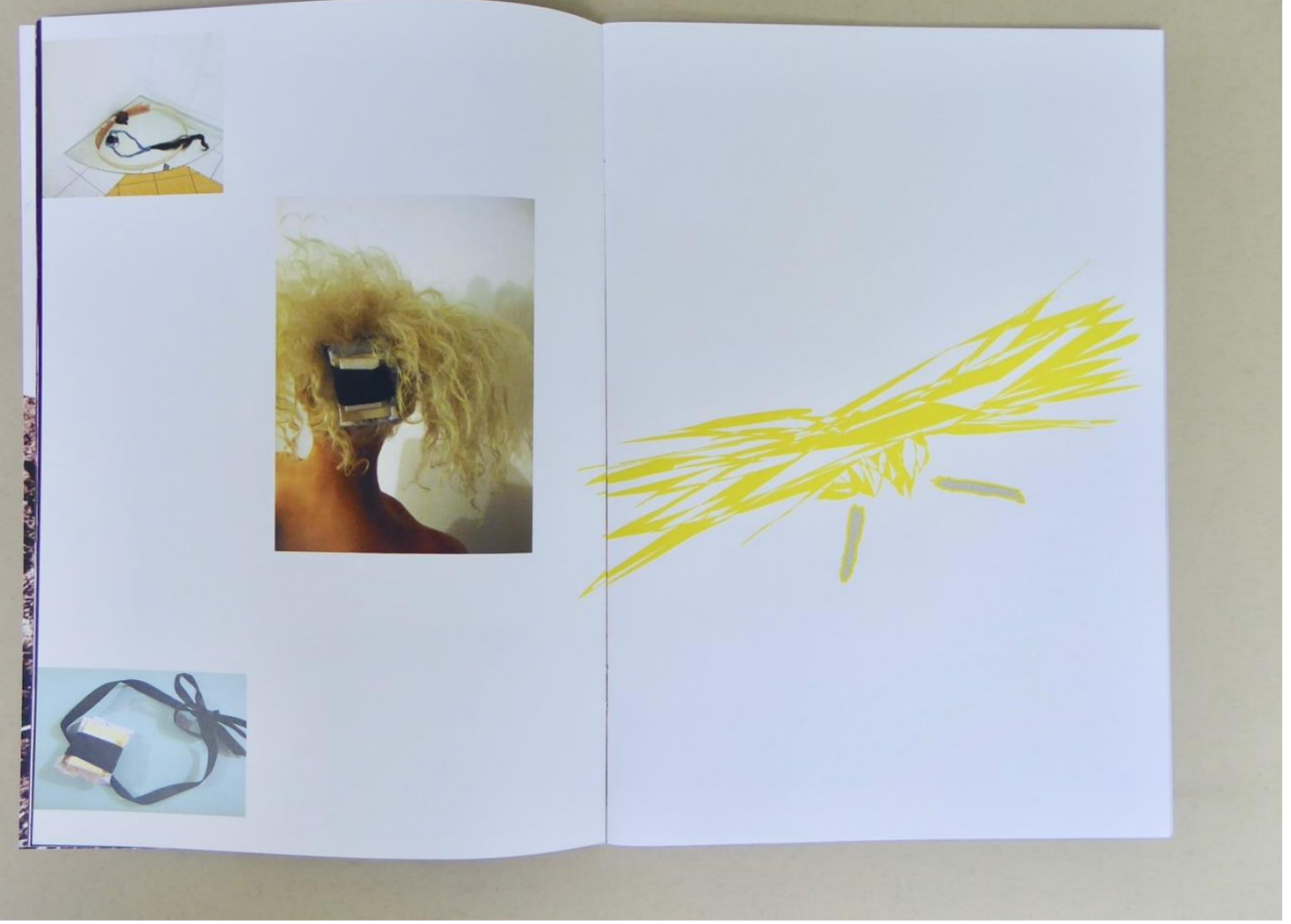

Figure 22 Canarezza \& Coro, Salon Devolution / Short stories of non-independence, p. 10-11.

destroyed by a car crash) to address an urgent issue: the danger on the Sammarinese highway and the disrespect this showed to the minority of people walking the streets or waiting for the bus (mostly students, elderly and foreigners).

The book 'ends' circularly by referring back to the beginning. After the whole journey through the second world war seen from San Marino, the view of a small state as a night club (fig. 21, left), people being run over on the highway and the hairdressers project in Japan and Iceland, the inclusion of pictures of undefined flying objects is 'explained' by a little drawing. ${ }^{166}$ This depicts the artists performing in the same pose and place as on the front cover (fig. 23). The scene is set in front of the Kursaal palace in the Sammarinese historical centre, the current headquarters of the Sammarinese broadcasting services and former casino. This was opened in 1949 under the Sammarinese social-communist government (the only one in the Western block, taken down by a coup against the 'red Republic' in 1957). ${ }^{167}$ The Italian government did not approve the opening and closed the border, de facto isolating San Marino. ${ }^{168}$ Therefore, the Kursaal palace symbolises the persistent negotiations around questions

166 Canarezza and Coro.

167 Rossi, 'La Guerra Tiepida: Una Storia Dimenticata'.

168 Rotelli, 'Assediati per Gioco'. 


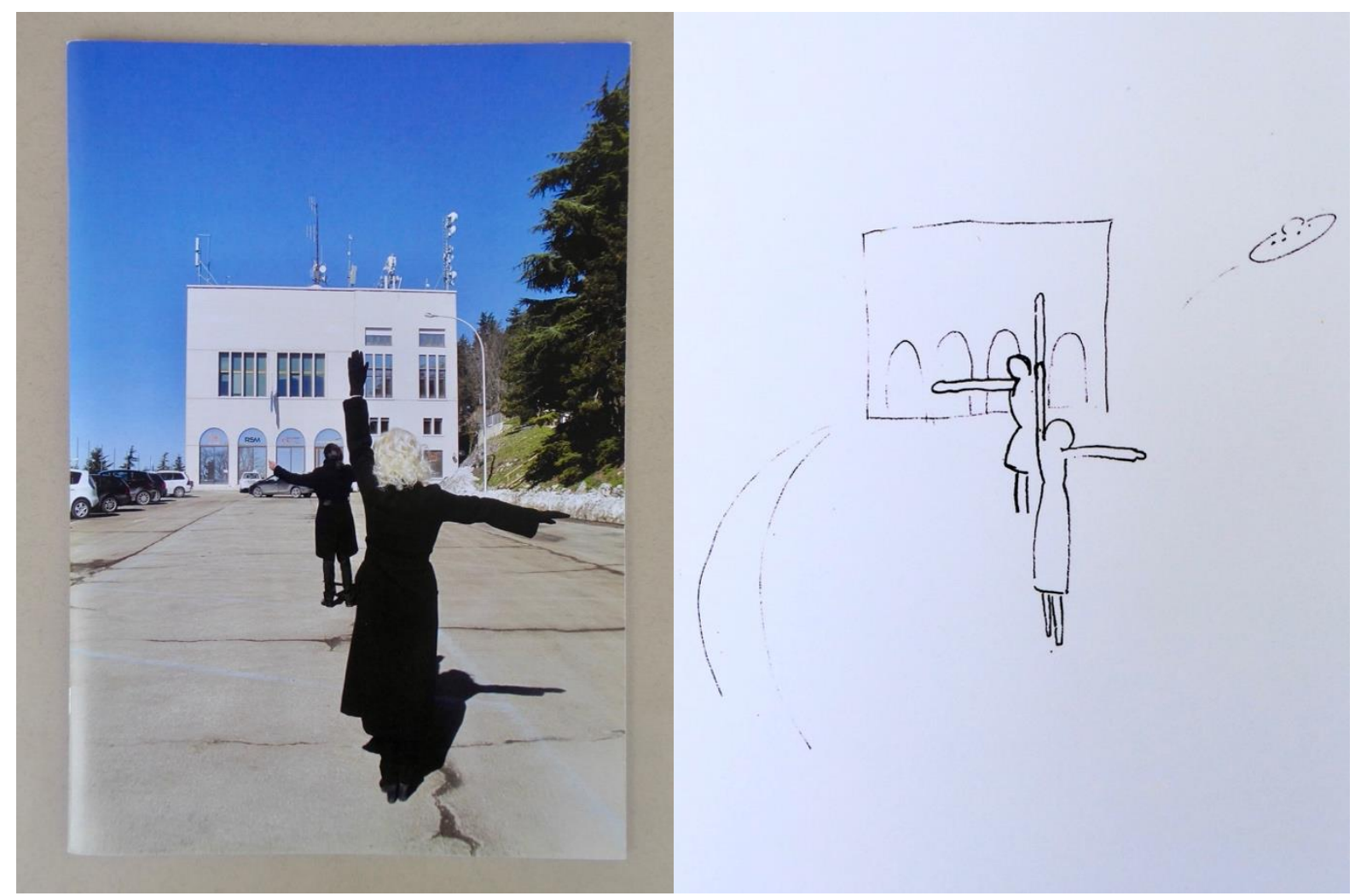

Figure 23 Canarezza \& Coro, Salon Devolution / Short stories of non-independence, p. 1, 22.

of communication and independence, which are ultimately the struggle for survival -or disappearance- of the Republic.

Looking at the drawing (fig. 23, right), it becomes clear that Canarezza \& Coro were performing signs -again, communication- to a UFO/spaceship. The artists talk about a feeling of being trapped at home and not understood. Moreover, they underline the need, characterising the whole Little Constellation project, to look elsewhere for solutions to similar problems: re-working smallness from a hindrance into an advantage. ${ }^{169}$ The artists' stance towards extra-terrestrial entities stays ambiguous. They seem to show a "smiling respect for the ungraspable," 170 the hallmark of Schlegelian irony. Indeed, a parallel could be drawn between Canarezza \& Coro's role in their work and the one foreseen for artists by (German) Romantics. Artists (should) act almost as prophets and carry a double burden: "the special, unqualified commitment to their own, personal vision and the universal responsibilities imposed by an obligation to serve humanity."171 The Sammarinese artists are often protagonists of their own work: they look for help from the stars (e.g. other artists in other small areas), they simulate and warn against unpleasant exaggerations of the present (e.g. the small

169 Canarezza and Coro, On 'Salon Devolution / Short stories of non-independence'.

170 Safranski and Goodwin, Romanticism: 36.

171 Sheehan, German History, 1770-1866: 331. 
state as a night club, fig. 21 left). Therefore, as for romantic artists, their subjective view could bring social change in the Republic.

The addition of UFOs was also suggested by the coincidental meeting -another time and space referenced in the work- of a friend of the artists who, on the same day, was looking for signs of mysterious energies between the second and third tower on top of the historical centre of San Marino. Photos by the friend are reported in the book as another way of subjectively mapping disappearances. The inclusion of this meeting highlights again the way the book is structured around layering and jumps in times and spaces according to small narrative units (e.g. individual works/projects). This multiplicity and fragmentation assure polyrhythmia and frequent arrhythmias, often puzzling the readers in their search for a comprehensive narrative.

Coro said that their fanzine had no time. ${ }^{172}$ I would interpret this statement by going back to the concept of the exhibition. Disappearance may mean something without or out of time and space, where the two dimensions disappear; perhaps the same way fables are told to be timeless, never really born and never getting old. Canarezza \& Coro's work references historical facts, it includes previous projects and it relies on their stories as contributions to the whole. However, even these times and spaces are produced in the reading and mapped 'subjectively'. For example, the bombings in 1944 are (re)constructed in the time and space of the book according to the authors' artistic intention and point of view as Sammarinese artists. Past and future times and spaces entangle (but never dissolve) in the present of the reading producing multiple rhythms, whether harmonious or disharmonious. Mapping as storytelling then would not be meant to describe, as an ethnographic work, but rather as a speculative gesture dealing with "conditions and possibilities," ${ }^{173}$ chances, coincidences, ideas and myths.

\section{Conclusion}

"Living in a small state gives you a different perspective of distance and time,"174 maintain Canarezza and Coro. It would have been impossible to empirically test such a statement, let alone through a dozen artists' books. The small areas members of the network have nearly nothing in common to start with, but they all seem to be worried,

\footnotetext{
172 Canarezza and Coro, Salon Devolution / Short Stories of Non-Independence.

173 Research Centre Art \& Society, Keynote Speech Tim Ingold.

174 Canarezza and Coro, Little Constellation: Small States on Un-Certain Stereotypes.
} 
whether as communities or as individuals, about their present and future as small and therefore non-self-sufficient entities pushed into a globalized international arena. The personal fear and stories of disappearance which stem from this situation landed into artists' books which, as "research for art and design"175 and/or "anthropological art,"176 embody unique perspectives on this issue. The 34 projects take the exhibition concept, with the two main themes 'subjective maps' and 'disappearances', to completely different directions, reflecting the extreme variety of practices and concerns within the network. The exhibition, re-collecting these practices under the umbrella label of small -and therefore somehow peculiar- areas builds a standing and legitimacy in the art arena that they may not have had on their own.

Starting from the view that "mapmaking is a form of storytelling", I outlined how the time and space of disappearances could be analysed in artists' books. I tried to take a step back from conventions, both in literary and art-historical analysis, to examine the books in the specificity of their plurimedial genre. Drawing on Lefebvre's rhythmanalysis, I argued that time and space are brought together in rhythms through materiality, that is the interplay between the physical object and its signifying strategies. It follows that time and space in the works are not pre-given, but they emerge in the interaction with the reader, who is not a 'disembodied' viewer, but needs to physically interact with the work to make sense of it. It is through rhythms that time and space come together, in cyclical and linear repetition and difference. Many different times and spaces are produced both by signifying strategies and by intermediality (i.e. transposition, combination and reference). This layering, together with the fragmentation resulting from the challenge of reading/printing conventions, shapes and multiplies the rhythms experienced in the works (e.g. polyrhythmia). In their four dimensions, books can be used both as narrative and documentary objects, to tell stories and to map both in time and space. In the works, disappearance is recounted and countered by creating objects which embody spatio-temporal narratives not bound to time and space as universal categories of experience.

\footnotetext{
175 Frayling, 'Research in Art and Design': 5.

176 Research Centre Art \& Society, Keynote Speech Tim Ingold.
} 


\section{Acknowledgements}

This thesis would not have been possible without the support of the National Gallery San Marino and the Cultural Institutes of the Republic of San Marino, which made the artworks available notwithstanding the ongoing emergency closure of all museums due to the current pandemic. In particular, I thank Rita Canarezza, cultural operator and project coordinator of the National Gallery San Marino, for giving me access to all the Little Constellation publications. Moreover, I thank the curators and interviewees, Halldór Björn Runólfsson, Alessandro Castiglioni, Rita Canarezza and Pier Paolo Coro, for their precious contributions and availability for discussion.

\section{Declaration}

I hereby declare, that I am the sole author and composer of my bachelor thesis and that no other sources or learning aids, other than those listed, have been used. Furthermore, I declare that I have acknowledged the work of others by providing detailed references of said work.

I hereby also declare, that my bachelor thesis has not been prepared for another examination or assignment, either wholly or excerpts thereof.

I declare that the submitted electronic version of the bachelor thesis corresponds in content and formatting to the hard copy.

Place, date

Signature 


\section{Bibliography}

Ashby, Lyn. 'Coming to Our Senses with a Modern Mythic Form: Postliteracy in Artistsbooks'. Journal of Artists' Books 39, no. Spring (2016).

Attalidou, Katerina. In the Memory of My Mother Niki Marangou. 2013. Artists' book. National Gallery San Marino.

Baldacchino, Godfrey. 'Bursting the Bubble: The Pseudo-Development Strategies of Microstates'. Development and Change 24, no. 1 (January 1993): 29-52. https://doi.org/10.1111/j.1467-7660.1993.tb00476.x.

Blau, Justine. ATLAS - 12 Embroidery Designs. 2013. Artists' book. National Gallery San Marino.

Bolter, Jay David, and Richard Grusin. Remediation: Understanding New Media. 6. Cambridge, Mass.: MIT Press, 2003.

Borges, Jorge Luis. 'On Exactitude in Science'. In Collected Fictions, translated by Andrew Hurley, n.d. https://kwarc.info/teaching/TDM/Borges.pdf.

Borges, Jorge Luis, Margarita Guerrero, and Norman Thomas Di Giovanni. The Book of Imaginary Beings. London: Vintage, 2002.

Bourriaud, Nicolas. Relational Aesthetics. Reprint. Documents Sur l'art. Dijon: Presses du réel, 2009.

Brown, Matthew. 'Book Arts and the Desire for Theory'. Journal of Artists' Books 22, no. Fall (2007).

Bury, Stephen. Artists' Books: The Book as a Work of Art, 1963-1995. Aldershot, Hants, England; Brookfield, Vt., USA: Scolar Press, 1995.

Canarezza, Rita, Alessandro Castiglioni, Pier Paolo Coro, and Halldór Björn Runólfsson. Subjective Maps: Disappearances. Milano: Mousse Publishing, 2013.

Canarezza, Rita, and Pier Paolo Coro. Little Constellation: Small States on UnCertain Stereotypes. Box of 14 DVDs. Mousse Publishing, 2012.

—. On Little Constellation. Skype call, 1 April 2020.

- On 'Salon Devolution / Short stories of non-independence'. Skype call, 10 April 2020.

Salon Devolution / Short Stories of Non-Independence. 2013. Artists' book. National Gallery San Marino. 
Candlin, Fiona. 'Practice-Based Doctorates and Questions of Academic Legitimacy'. International Journal of Art and Design Education 19, no. 1 (2000): 96-101. https://eprints.bbk.ac.uk/737/.

Castiglioni, Alessandro. On Subjective maps / Disappearances. Skype call, 13 April 2020.

Castiglioni, Alessandro, Rita Canarezza, and Pier Paolo Coro. The Land Seen from the Sea. Mousse Publishing, 2012.

Chen, Yi. “'Walking With”: A Rhythmanalysis of London's East End'. Culture Unbound: Journal of Current Cultural Research 5, no. 4 (12 December 2013): 531-49. https://doi.org/10.3384/cu.2000.1525.135531.

Daolio, Roberto. 'Little (Big) Constellation'. In Little Constellation: Contemporary Art in Geo-Cultural Micro-Areas and Small States of Europe, 42-43. Milan: Mousse Publishing, 2010.

De Bernardo, Oppy. [Installation at the National Gallery of Iceland for Subjective Maps / Disappearances]. 2013. Installation.

http://www.littleconstellation.org/project_eng.php?act=dettaglio\&id_materiale= 1335.

Drucker, Johanna. The Century of Artists' Books. New York City: Granary Books, 1995.

Dumienski, Zbigniew. 'Microstates as Modern Protected States: Towards a New Definition of Micro-Statehood'. Institute of International Affairs - The Centre for Small State Studies (University of Iceland), Occasional Paper, 2014.

Duncombe, Stephen. Notes from Underground: Zines and the Politics of Alternative Culture. 2. ed. Bloomington: Microcosm, 2008.

Elden, Stuart. Understanding Henri Lefebvre: Theory and the Possible. Continuum Studies in Philosophy. London; New York: Continuum, 2004.

'Eurhythmia'. In Medical Dictionary for the Health Professions and Nursing. Accessed 18 April 2020. https://medical-dictionary.thefreedictionary.com/eurhythmia.

Frayling, Christopher. 'Research in Art and Design'. Royal College of Art, RCA Research papers, 1, no. 1 (1993).

Giardi, Chiara. Map of the Little Constellation Network. 2020.

Harkin, Patricia. 'The Reception of Reader-Response Theory'. College Composition and Communication 56, no. 3 (2005): 410-25.

Hayles, Katherine. 'Print Is Flat, Code Is Deep: The Importance of Media-Specific Analysis'. Poetics Today 25, no. 1 (Spring 2004). 
'ICOM Statutes'. Accessed 2 February 2020.

http://archives.icom.museum/statutes.html.

Joensen, Unn. Liv-ð Left Overs. 2013. Artists' book. National Gallery San Marino.

Klieger, P. Christia. Microstates of Europe: Designer Nations in a Post-Modern World. Lanham; Lanham: Lexington Books Rowman \& Littlefield Publishers, Incorporated [distributor, 2014. http://public.ebookcentral.proquest.com/choice/publicfullrecord.aspx?p=11171 33.

Larese, Dino. 'Das Nachtvolk'. Sagen.at. Accessed 27 April 2020.

http://www.sagen.at/texte/sagen/liechtenstein/larese/nachtvolk.html.

Le Ruez, Simon. Elsewhere. 2013. Artists' book. National Gallery San Marino.

Lefebvre, Henri. Rhythmanalysis: Space, Time, and Everyday Life. London ; New York: Continuum, 2004.

- The Production of Space. Translated by Donald Nicholson-Smith. Oxford: Blackwell Publishing, 1974.

Little constellation: contemporary art in geo-cultural micro-areas and small States of Europe. Milan, Italy: Mousse Publishing, 2010.

'Littleconstellation'. Accessed 2 February 2020. http://www.littleconstellation.org/mission_eng.php.

Macken, Marian. 'Designing with/for/through the Existing: Artists' Books and Documentation'. Journal of Artists' Books 39, no. Spring (2016).

Malinowski, Bronisław. Argonauts of the Western Pacific. New York: London, G. Routledge \& Sons; New York, E.P. Dutton \& Co., 1922.

Mallard i Casamajor, Lluís, and Jordi Domingo i Coll. 'Small communities with big complexities in the sphere of interaction'. In Little constellation: contemporary art in geo-cultural micro-areas and small States of Europe, 51-52. Milan, Italy: Mousse Publishing, 2010.

'[Map of Little Constellation for Subjective Maps / Disappearances]'. In Subjective Maps / Disappearance. Milan, Italy: Mousse Publishing, 2013.

McLuhan, Marshall. Understanding Media: The Extensions of Man. 1st MIT Press ed. Cambridge, Mass: MIT Press, 1994.

Mitchell, W. J.T. 'There Are No Visual Media'. Journal of Visual Culture 4, no. 2 (August 2005): 257-66. https://doi.org/10.1177/1470412905054673.

Montero, Gustavo Grandal. 'Artists' Books in HE Teaching and Learning', 2012. https://pdfs.semanticscholar.org/f042/541e4e2954c126ec8a80ff0ec327e4466 181.pdf. 
Morton, Adam David. 'The Warp of the World: Geographies of Space and Time in the Border Trilogy by Cormac McCarthy'. Environment and Planning D: Society and Space 33, no. 5 (October 2015): 831-49. https://doi.org/10.1177/0263775815604919.

Myers, Ann K.D., and William Andrew Myers. 'Opening Artists' Books to the User: An Example with Potential Approaches'. RBM: A Journal of Rare Books, Manuscripts, and Cultural Heritage 15, no. 1 (1 March 2014): 56-67. https://doi.org/10.5860/rbm.15.1.415.

Nikcević, Teodora. Disappearances. 2013. Artists' book. National Gallery San Marino.

Obert, Julia C. 'Sound and Sentiment: A Rhythmanalysis of Television'. Continuum 22, no. 3 (June 2008): 409-17. https://doi.org/10.1080/10304310701739463.

Pasolini, Pier Paolo. [The Deposition]. 1963. Film still from 'La Ricotta'. https://www.artribune.com/arti-performative/cinema/2017/11/pittura-sacra-laricotta-pier-paolo-pasolini-pontormo-rosso-fiorentino/.

Piccioni, Elisabetta. 'Il Viaggio Interrotto: La Ferrovia Elettrica Rimini-San Marino'. I Martedi San Marino inedito, no. 292 (2011): 18-22.

Piepmeier, Alison. 'Why Zines Matter: Materiality and the Creation of Embodied Community'. American Periodicals: A Journal of History, Criticism, and Bibliography 18, no. 2 (2008): 213-38. https://doi.org/10.1353/amp.0.0004.

Portelli, Pierre. STRADAMERKANTI. 2013. Artists' book. National Gallery San Marino.

Rajewsky, Irina O. 'Intermediality, Intertextuality, and Remediation: A Literary Perspective on Intermediality'. Intermédialités, no. 6 (10 August 2011): 43-64. https://doi.org/10.7202/1005505ar.

Research Centre Art \& Society. Keynote Speech Tim Ingold: Art, Science and the Meaning of Research (November 2017, Groningen), 2017. https://vimeo.com/244644301.

Rossi, Valentina. 'La Guerra Tiepida: Una Storia Dimenticata'. I Martedì San Marino inedito, no. 292 (2011): 24-29.

Rotelli, Enrico. 'Assediati per Gioco'. In Storia Illustrata Della Repubblica Di San Marino, Vol. 4. II Piccolo Stato. San Marino: AIEP editore, 1995.

Roth, Dieter. 2 Bilderbücher. 1976. Spiral binding book. Fondazione Bonotto. https://www.fondazionebonotto.org/en/collection/fluxus/rothdieter/1715.html.

Roux, Agnès. Lost Crown. 2013. Artists' book. National Gallery San Marino.

Runólfsson, Halldór Björn. On Subjective Maps / Disappearances. Skype call, 24 April 2020. 
Safranski, Rüdiger, and Robert E. Goodwin. Romanticism: A German Affair. Evanston, Illinois: Northwestern University Press, 2014.

[Selection of Artists' Books for Subjective Maps / Disappearances]. 2013. Artists' books. National Gallery San Marino.

Sheehan, James J. German History, 1770-1866. Oxford History of Modern Europe. Oxford [England] : New York: Clarendon Press ; Oxford University Press, 1989.

Simpson, Paul. 'Apprehending Everyday Rhythms: Rhythmanalysis, Time-Lapse Photography, and the Space-Times of Street Performance'. Cultural Geographies 19, no. 4 (October 2012): 423-45. https://doi.org/10.1177/1474474012443201.

Snell, Eric. All at Sea. 2013. Artists' book. National Gallery San Marino.

Sundberg, Martin. 'The Collapse of the Word-Image Dichotomy: Towards an Iconic Approach to Graphic Novels and Artists' Books'. Konsthistorisk Tidskrift/Journal of Art History 86, no. 1 (2 January 2017): 31-44. https://doi.org/10.1080/00233609.2016.1237541.

Thomas, Susan. 'Value and Validity of Art Zines as an Art Form'. Art Documentation: Journal of the Art Libraries Society of North America 28, no. 2 (2009): 27-36, 38.

Tietz, Ward. 'Artists' Books: Between Viewing and Reading'. Journal of Artists' Books 21, no. Spring (2007).

Veenendaal, Wouter. 'Size and Personalistic Politics: Characteristics of Political Competition in Four Microstates'. The Round Table 102, no. 3 (June 2013): 245-57. https://doi.org/10.1080/00358533.2013.794582.

. 'The Economic Crisis and the Republic of San Marino: A Comparative Case Study'. In Section 28 (Small States and the Global Economy) Panel 204 (The Politics and Political Economy of Tiny European States). Reykjavik, Iceland: The European Consortium for Political Research, 2011. https://ecpr.eu/Filestore/PaperProposal/643493a0-1d77-47fb-8b62c6d8f0dd2a80.pdf.

Zweig, Janet. 'Artists, Books, Zines'. Afterimage 26, no. 1 (1998). 
Annex A: List of Artists' Books and Fanzines

\begin{tabular}{|c|c|c|c|}
\hline $\begin{array}{l}\text { No. } \\
\text { Catalogue }\end{array}$ & Author(s) & Micro-area & Title \\
\hline 01 & $\begin{array}{c}\text { Rita Canarezza \& Pier } \\
\text { Paolo Coro }\end{array}$ & San Marino & $\begin{array}{l}\text { Salon Devolution } \\
\text { Short stories of non- } \\
\text { independence }\end{array}$ \\
\hline 02 & $\begin{array}{l}\text { Lorella Mussoni \& Pier } \\
\text { Giorgio Albani and María } \\
\text { Pétursdóttir }\end{array}$ & $\begin{array}{l}\text { San Marino + } \\
\text { Iceland }\end{array}$ & $\begin{array}{l}\text { Two warriors and their } \\
\text { battle... against the monster }\end{array}$ \\
\hline 03 & Ingibjörg Magnadóttir & Iceland & Pað er enginn hér \\
\hline 04 & Sigurður Atli Sigurðsson & Iceland & Blitz der Wut \\
\hline 06 & Bjargey Olafsdóttir & Iceland & $\begin{array}{c}\text { In the end all we care about is } \\
\text { love }\end{array}$ \\
\hline 05 & Sigtryggur Berg Sigmarsson & Iceland & $\begin{array}{c}\text { Minimal Avant Garde Difficult } \\
\text { Conceptual } \\
\text { Naïve Outsider Art } \\
\end{array}$ \\
\hline 07 & Hekla Dögg Jónsdóttir & Iceland & Disappear \\
\hline 08 & Dustin Cauchi & Malta & Mutter ich bin dumm \\
\hline 09 & Mark Mangion & Malta & $\begin{array}{c}\text { Parallel Borders } 1 \\
\text { Monuments and shrines to } \\
\text { Capitalism, Europe } 2013 \\
\end{array}$ \\
\hline 10 & Pierre Portelli & Malta & Stradamerkanti \\
\hline 11 & Agnès Roux & Monaco & Lost crown \\
\hline 12 & Daniel Arellano Mesina & Andorra & Fanzine \\
\hline 13 & Eve Ariza & Andorra & Bla's smuggler route \\
\hline 14 & Helena Guàrdia & Andorra & $\begin{array}{c}\text { Andorra } \\
\text { (A5 thick paper) }\end{array}$ \\
\hline 14 & Helena Guàrdia & Andorra & (A4 regular paper) \\
\hline 15 & Barbara Geyer & Liechtenstein & $\begin{array}{c}\text { Subjective maps } \\
\text { disappearance }\end{array}$ \\
\hline 16 & Martin Walch & Liechtenstein & Das Nachtvolk \\
\hline 17 & Justine Blau & Luxembourg & $\begin{array}{c}\text { ATLAS: } 12 \text { embroidery } \\
\text { designs }\end{array}$ \\
\hline 18 & Doris Drescher & Luxembourg & $\begin{array}{l}\text { subjective maps } \\
\text { disappearance }\end{array}$ \\
\hline 19 & Trixi Weis & Luxembourg & Will art disappear? \\
\hline 20 & Victoria Leonidou & Cyprus & Lucomorye \\
\hline
\end{tabular}




\begin{tabular}{|c|c|c|c|}
\hline 21 & Katerina Attalidou & Cyprus & $\begin{array}{c}\text { In the memory of my mother } \\
\text { Niki Marangou }\end{array}$ \\
\hline 22 & Irena Lagator Pejović & Montenegro & Disappearance \\
\hline 23 & Teodora Nikcević & Montenegro & Disappearances \\
\hline 24 & Jelena Tomašević & Montenegro & \\
\hline 25 & Natalija Vujošević & Montenegro & Shithole discotheque \\
\hline 26 & Oppy De Bernardo & Canton Ticino & \\
\hline 27 & Miki Tallone & Canton Ticino & Can you give me my position? \\
\hline 28 & Nina Danino & Gibraltar & Meteorologies \\
\hline 29 & Minna Öberg & Åland Islands & How do I get there? \\
\hline 30 & Pauliina Turakka Purhonen & Åland Islands & Hemresan \\
\hline 31 & Jóhan Martin Christiansen & Faroe Islands & This, like orange \\
\hline 32 & Unn Joensen & Faroe Islands & Liv-ð Left Overs \\
\hline 33 & Eric Snell & Guernsey & All at sea \\
\hline 34 & Simon Le Ruez & Jersey & Elsewhere \\
\hline
\end{tabular}

\section{About the author:}

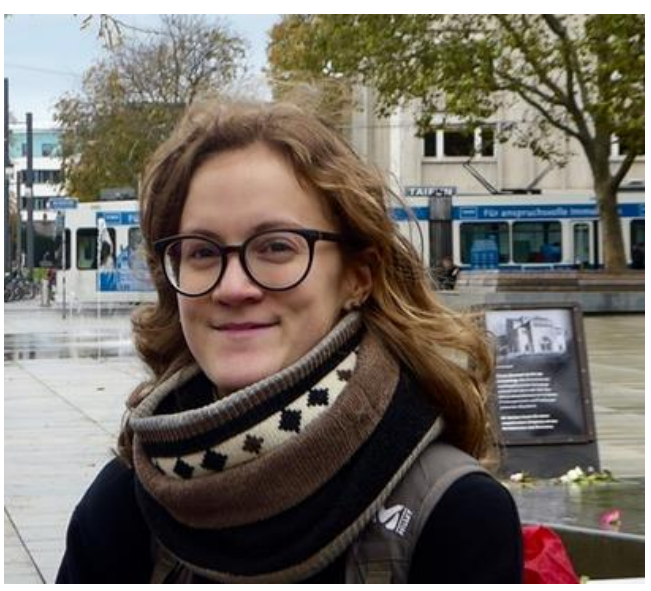

Chiara Giardi was born and grew up in the Republic of San Marino. She attended an artistic high school with A-Levels in Figurative Arts: Painting. In 20142015, she participated in a year-long cultural exchange program in Trad, Thailand, where she attended a local high school and was hosted by a local family. In 2016 she moved to Freiburg i. Br., Germany, to study Liberal Arts and Sciences (BA), major Culture and History at the University College Freiburg (AlbertLudwigs-University). In 2018-2019 she studied, thanks to a year-long Erasmus + program, at the University College Groningen (Rijksuniversiteit Groningen, The Netherlands), where she researched on intersections between artistic practice and academic research interviewing artists and academics working on an Art-Science project. She has worked as an intern for cultural institutions, such as the National Gallery San Marino and ATELIERFRANKFURT and exhibited internationally as an artist. From September 2020, she will continue to pursue her interdisciplinary path in contemporary art with an MA in Art Education, Curatorial studies at the University of the Arts in Zurich (ZHdK; Switzerland). 